\title{
Hydroclimate Variability and Change over the Mekong River Basin: Modeling and Predictability and Policy Implications
}

\author{
ALFREDO RUIZ-BARRADAS \\ Department of Atmospheric and Oceanic Science, University of Maryland, College Park, \\ College Park, Maryland \\ SUMANT NIGAM \\ Department of Atmospheric and Oceanic Science, University of Maryland, College Park, College Park, \\ Maryland, and Jefferson Science Fellowship Program, National Academy of Sciences, Washington, D.C.
}

(Manuscript received 17 October 2017, in final form 2 April 2018)

\begin{abstract}
The Mekong River is the lifeblood of the Southeast (SE) Asian economies. In situ and satellite-based precipitation are analyzed to assess the amount of water received as precipitation in the river basin (Mekong basin water), in particular, the amount each country receives. Laos, Thailand, and Cambodia contribute $\sim 75 \%$ of the basin water during March-September, whereas China's contribution is 10\%-15\%, except in winter when it rises to $25 \%$. The processing of Mekong basin water into Mekong streamflow entails accounting for the uncertain water losses but, interestingly, interannual variations in Mekong basin water can be processed into Mekong streamflow using a simple hydrologic model, which is validated using monthly river discharge data from four stations. Preliminary evidence for the impact of upbasin dams on downstream flow, especially the timing of peak summer flow, is presented. Characterization of El Niño's influence on SE Asian rainfall reveals significant rainfall reductions in the fall preceding and the spring following El Niño's peak phase (winter); such reductions at the bookends of the dry season in SE Asia (winter) generate droughts, as in 2015-16. The linear trend in twentieth-century rainfall assesses the vulnerability of the region to climate change. The analysis indicates the feasibility of streamflow prediction using a simple hydrologic model driven by high-resolution precipitation observations and forecasts. It raises the prospects of drought prediction based on El Niño's emergence/forecast. Finally, by showing the Mekong to be largely a rain-fed and not snowmelt-fed river, it provides quantitative context for assessing the notion of Chinese control on the lower Mekong via upbasin dams.
\end{abstract}

\section{Introduction}

The transboundary Mekong River winds its way through six countries, with a basin larger than $700000 \mathrm{~km}^{2}$ and with more than 60 million people living in it. The Mekong is the longest river in the Indochina Peninsula, with the greater Mekong being one of the most biodiverse habitats in the world, second only to the Amazon in fish biodiversity (WWF 2017). The Mekong basin is shared by six countries: Thailand, Laos, China, Cambodia, Vietnam, and Myanmar, listed in order of their basin area (Table 1, left column). The Mekong basin can be divided into two regions based on physiography: the upper basin, with elevations higher than $1000 \mathrm{~m}$, lies mostly in southern

Corresponding author: Sumant Nigam,nigam@umd.edu
China while the lower basin, with elevations typically under $500 \mathrm{~m}$, extends from Laos and Myanmar in the north to Cambodia and Vietnam in the south. The lower basin is thus more extended, occupying large stretches of Indochina (Fig. 1).

Snowmelt and precipitation feed the Mekong River, but their varying amounts, seasonally and interannually, exert considerable stress on the regional water resources; for example, precipitation over the left-bank tributaries in Laos generates most of the peak wet-season discharge, including the occasional floods (MRC 2005; Adamson et al. 2009). The livelihoods and food security of the people in the Mekong basin are closely linked to the river, through fisheries, agriculture, hydropower, and industrial and human consumption. Over $60 \%$ of the economically active population has water-related occupations that are 
vulnerable to water-related shocks and degradation (FAO 2012). The extent of the region's dependence on the Mekong River is laid bare during periods of extreme drought (e.g., 2015-16) when communities along the river and in the estuaries (which depend on a subtle balance between river discharge and saline inundation) are impacted along with coastal biodiversity and fisheries (Son and Thuoc 2003). Floods and landslides have also cost the region dearly, with one estimate (Guha-Sapir et al. 2017) of the toll at $\sim 20000$ lives and $\sim 59$ billion U.S. dollars in economic losses since the 1980s.

The Mekong basin has significant exposure to climate variability, not unlike other monsoon regions in South Asia. The prominent seasonal circulation is the southwest monsoon, comprising low-level, moisture-laden, onshore winds from the southwest (i.e., Bay of Bengal, Andaman Sea, and the Gulf of Thailand), which usher in the rainy season (May-September). Northeastern India, northwestern Myanmar, and the lower Mekong are regions of very large summer monsoon rainfall (and also year-to-year rainfall variability; Yokoi et al. 2007). Not surprisingly, the Mekong River transitions from a shrunken winter state to a swollen summer state, consistent with the timing and magnitude of the peak wetseason discharge of large tropical monsoonal rivers.

Interannually, the Mekong basin is exposed to the robust influence of El Niño-Southern Oscillation (ENSO) - a key mode of interannual climate variability-with drought conditions in the warm ENSO phase (El Niño), as in 2015/16. This drought was, in fact, severe-reckoned to be one of the worst on record-with the Mekong River at record low levels and with extensive saline water intrusions into the Mekong Delta (Daiss 2016; Larson 2016; Office of the Resident Coordinator Viet Nam 2016).

Process-wise, the interannual variability of summer rainfall over the Mekong basin results from variations of the monsoon onset date and of moisture fluxes from the adjacent seas (Misra and DiNapoli 2014). The monsoon onset (and withdrawal) is sensitive to the ENSO state, especially the sea surface temperature (SST) variations in the western-central equatorial Pacific (Zhang et al. 2002; Räsänen et al. 2016). ENSO's largest impact on the Mekong basin precipitation and hydrology (e.g., river discharge) occurs during its decaying phase (Räsänen and Kummu 2013). Long-term tree-ring-based hydroclimate reconstruction from basin sites, especially in Vietnam, also show the regional droughts and floods to be linked to the interannual and interdecadal variations of tropical Pacific SSTs (Buckley et al. 2010; Delgado et al. 2012).

The hydroclimate footprints of climate change have not spared the lower Mekong either: recent trends and climate change projections indicate increasing surface air temperature and rising sea level in the region (Hijioka et al. 2014). Increasing minimum temperatures and a decreasing diurnal temperature range, especially in winter and spring (Bertiz 2017), are increasing human discomfort. The shallow continental shelf of the Mekong Delta (Fig. 1) increases susceptibility to salinity intrusions with rising sea level and diminishing streamflow (especially in the dry season of winter), endangering drinking water for the delta and coastal communities (Church et al. 2004; Hoque et al. 2016).

The Mekong basin's resilience is being further tested (and in some cases augmented) by the construction of dams along the main stem and tributaries of the Mekong (Fig. 1). Although helpful with hydropower, the upbasin dams have altered streamflow, leading to transboundary issues in water availability, fish migration, and sediment transport (Xue et al. 2011).

The increasing water stresses in the lower Mekong, notwithstanding their origin, warrant a regionally coordinated water management scheme. Development of a prediction system for near-term hydroclimate variability, especially droughts and floods, and robust characterization of the forthcoming hydroclimate change in the Mekong basin should be a high priority of regional governments and multinational institutions engaged in the planning and design of large infrastructure projects. Advancing predictive skill will require both an improved understanding of the regional processes and more definitive characterizations of the seasonal hydroclimate footprints of the leading modes of climate variability (e.g., ENSO) and of climate change.

The present analysis is water-centric. The precipitation, river discharge (interchangeably referred to as streamflow), physiography (with dam information), and SST datasets are described in section 2. Water arriving as precipitation in the Mekong basin-Mekong basin wateris the focus of section 3 , where the country receipts are estimated from the analysis of the state-of-the-art in situ and satellite-based high-resolution precipitation datasets. Mekong streamflow concerns section 4 . The volume of water received as precipitation in the basin northward of a river gauge station is related to the streamflow at that station in this section, working off the premise that a generally southward-sloping basin terrain will gravitationally organize the streamflow after the customary losses from evapotranspiration, soil moisture recharge/ storage, and infiltration. The relationship is investigated both for the climatology and anomaly (i.e., departures from climatology) fields, at monthly resolution. The anomaly fields were targeted with the hope of obtaining a more direct relationship between the upbasin precipitation volume and streamflow since some of the 


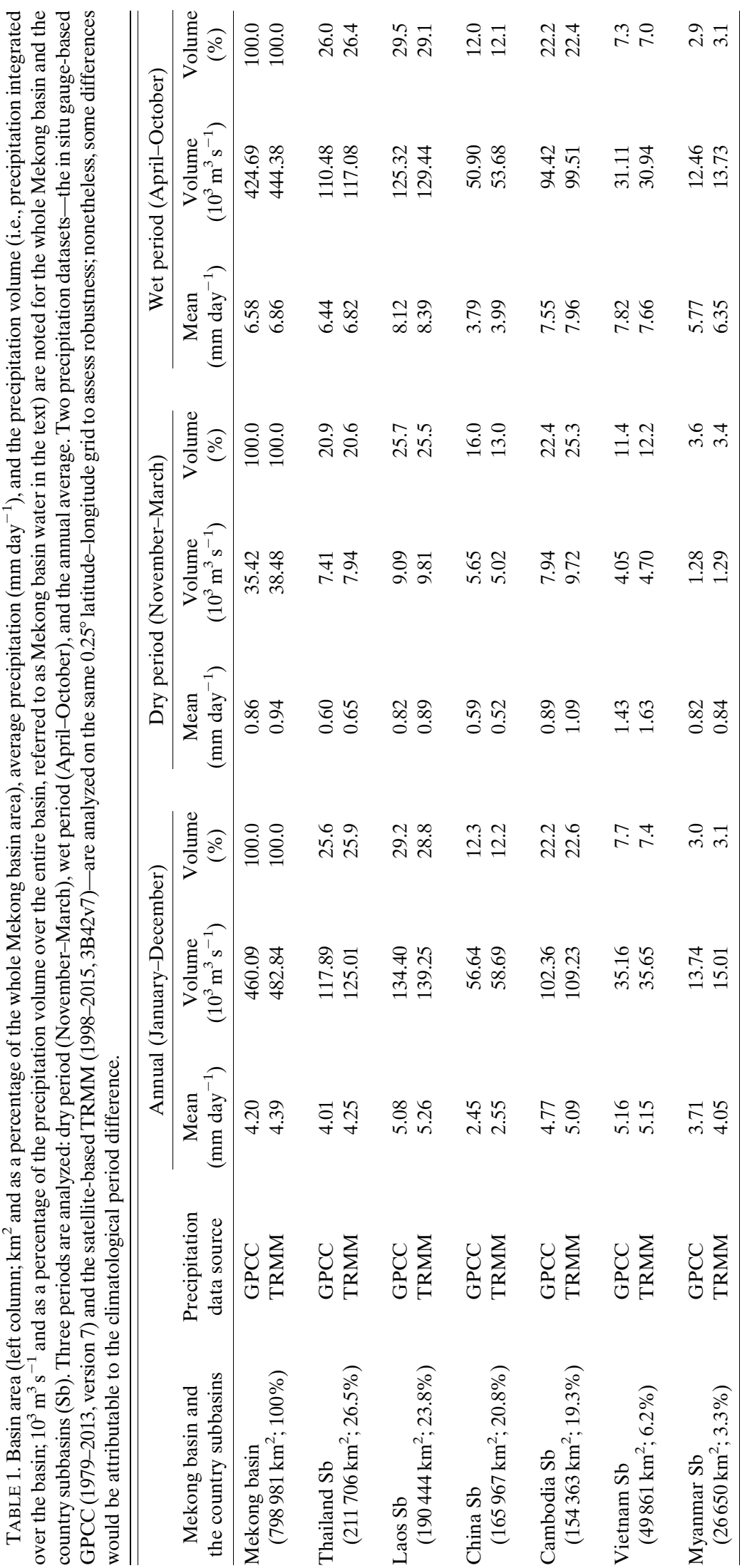




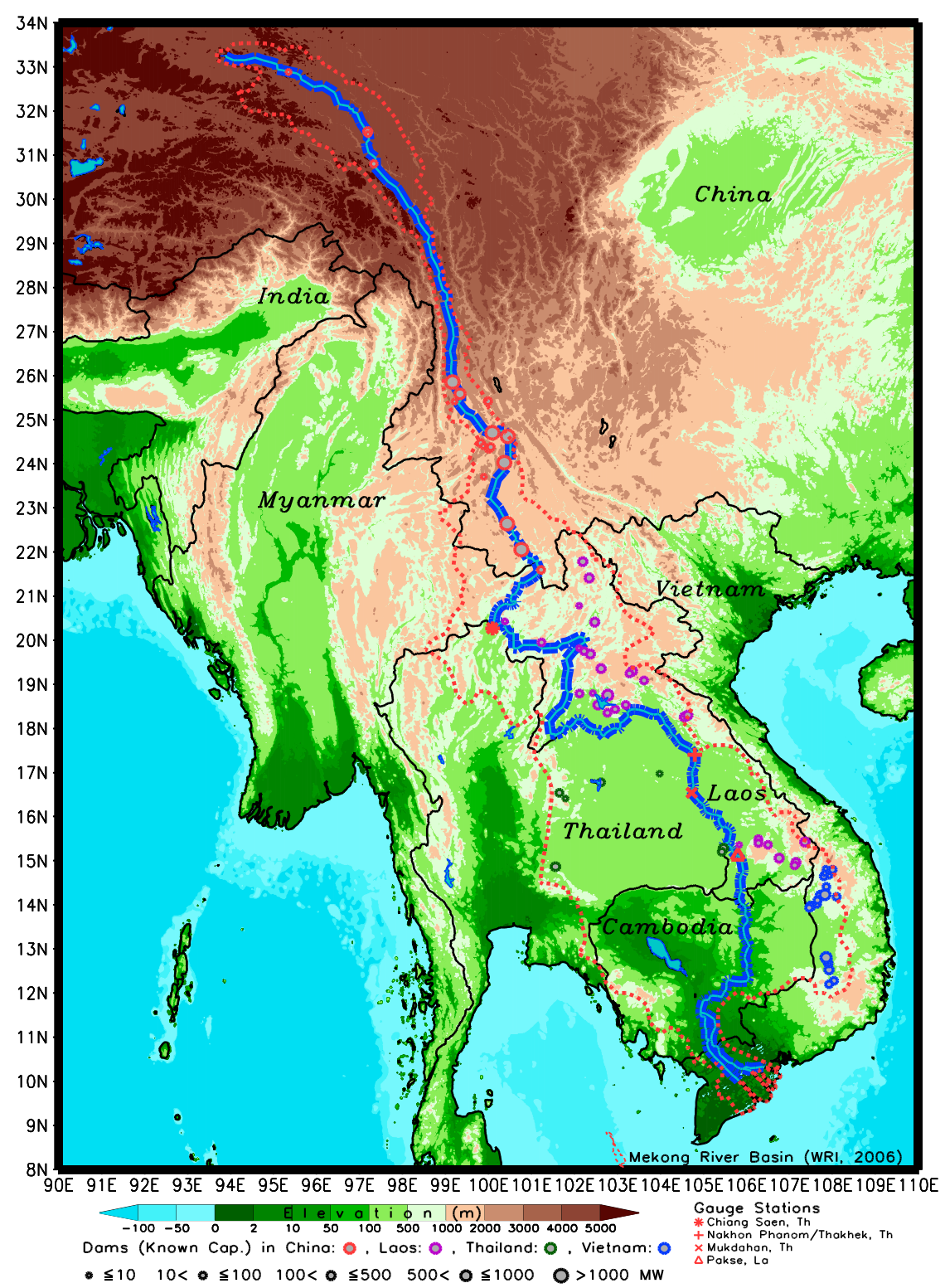

FIG. 1. Features and regional context of the Mekong River basin. Brown/green shading denotes elevation $(\mathrm{m})$, and blue shading denotes the bathymetry from NOAA's ETOPO1 1-arc-min ( $\sim 1.5-\mathrm{km}$ resolution; Amante and Eakins 2009) data; elevations less than $10 \mathrm{~m}$ are deltas, and depths less than $50 \mathrm{~m}$ are the coastal shelves. Blue lines mark the Mekong River, and the dashed red lines outline the river basin (WRI; Jenness et al. 2007a,b). Dams already commissioned within the basin in China (filled red circles), Laos (filled purple circles), Thailand (filled green circles), and Vietnam (filled blue circles) are marked, with circle size indicative of the hydropower capacity, as per legend; dam locations were obtained from CGIAR (2017). Four river gauge stations with extended historical records are marked with red symbols: three in Thailand [Chiang Saen $(*)$, Nakhon Phanom/Thakheh $(+)$, and Mukdahan $(\mathrm{x})]$ and one in Laos [Pakse $(\Delta)$ ]. Tributaries of the Mekong River are not displayed for clarity.

losses (e.g., soil moisture storage, infiltration) may be less variable.

The anomaly analysis leads to the emergence of a simple hydrologic model for the Mekong streamflow variations. Preliminary evidence for the impact of upbasin dams on downstream flow, especially on the timing of the peak summer flow, is presented in section 5 . The influence of El Niño on regional hydroclimate 
and the century-long (1901-2013) linear trends in basin precipitation are discussed in section 6 at seasonal resolution. A summary of the research findings and their policy implications follow in section 7 .

\section{Datasets and analysis methods}

\section{a. Physiography data}

The analysis uses several physiographical datasets: spatial coverage of the Mekong basin is extracted from a shapefile containing major watersheds of the world [Watersheds of the World, World Resources Institute (WRI) (WRIBASIN); Jenness et al. 2007a,b]; the file was obtained via the UN's FAO website (http://ref.data.fao.org/ map? entryId=8a3f1390-e28c-11db-a939-000d939bc5d8). The WRIBASIN shapefile data layer is composed of 254 major river basin features based on $\sim 250000$ cells of data originally from WRI-Rutgers. Rivers and country boundaries in Southeast (SE) Asia are obtained from the shapefiles in the Esri data and maps products of World Rivers and World Countries (generalized, 2012; https://www.arcgis.com/home/index.html).

The shapefiles of the Mekong basin and the country boundaries are used to create masks on a $0.25^{\circ}$ grid via the MeteoInfo software (Wang 2014), which is compatible with Grid Analysis and Display System (GrADS). The basin area lying in each country is computed on the $0.25^{\circ}$ grid using the GrADS function "asum", after weighting each gridcell area by the cosine of its central latitude. At this grid resolution, the Mekong basin is $798981 \mathrm{~km}^{2}$ in extent; Thailand contributes the most while Myanmar contributes the least to the basin area. The country subbasins are apparent in Fig. 1 where the Mekong basin and country boundaries are marked and quantitatively characterized in Table 1 where the basin area and basin fraction (\%) in each country are noted in the left column, for example, $26.5 \%$ of the Mekong basin is within Thailand. The basin fractions are, however, not necessarily indicative of their relative water contributions in view of the significant spatial and seasonal variation in rainfall.

Topography and bathymetry are obtained from the 1-arc-min global relief model of Earth's surface that integrates land topography and ocean bathymetry, ETOPO1 (Amante and Eakins 2009; the data were obtained from NOAA's National Oceanographic Data Center via https://www.ngdc.noaa.gov/mgg/global/global.html).

\section{b. Mekong basin dams}

The location of dams in the Mekong basin is obtained from the Research Program on Water, Land and Ecosystems dataset on dams (CGIAR 2017; https://wle-mekong. cgiar.org/maps/). The damming of the Mekong River is primarily driven by the hydropower potential, as apparent from the large (and increasing) number of main stem dams in the upper basin. The number of dams (in parentheses) has rapidly increased each decade since the 1960s: 1960-69 (2), 1960-79 (10), 1960-89 (13), 1960-99 (25), 1960-2009 (48), and 1960-2013 (81), with 8 operational dams along the main stem of the Mekong River (Fig. 1); 25 dams are not included in this accounting because the year in which they were commissioned was not available.

\section{c. Precipitation}

Although remotely sensed precipitation is preferred in complex terrains on account of the unrepresentativeness of the in situ station observations and the sparseness of the regional gauge network, as in the Mekong basin (Wang et al. 2016), the shortness of the satellite records necessitates consideration of the longer-term in situ records in the characterization of the precipitation climatology and variability. Two precipitation datasets are analyzed in this study: monthly precipitation on a $0.5^{\circ}$ continental grid from January 1901 to December 2013 from the Global Precipitation Climatology Centre (GPCC, version 7; Schneider et al. 2017a,b; https://www.esrl.noaa. gov/psd/data/gridded/data.gpcc.html) and daily precipitation on a $0.25^{\circ}$ tropical land-ocean grid from 1998 to 2016 from the joint NASA and Japan Aerospace Exploration Agency Tropical Rainfall Measurement Mission (TRMM) project (3B42 product, version 7; Huffman et al. 2007; https://disc2.gesdisc.eosdis.nasa.gov/data/TRMM_L3); this is an added-value product as the multisatellite measurements have been adjusted with rain gauge data.

The GPCC precipitation is interpolated from its native $0.5^{\circ}$ grid to the $0.25^{\circ} \mathrm{TRMM}$ grid using the GrADS "Iterp" function to facilitate the overlay of identical shape and country boundary files on both precipitation datasets. The volume of water from precipitation is obtained by multiplying the local precipitation rate by the area of that $0.25^{\circ} \times 0.25^{\circ}$ grid cell, followed by integration over the basin area lying within each country or the entire basin.

\section{d. River discharge (or streamflow)}

Discharge data are obtained for the Mekong gauge stations that have an uninterrupted monthly record over multidecadal periods; the data are sourced from the Augmented Monthly Flow Rates of World Rivers data archive at the National Center for Atmospheric Research (Dai and Trenberth 2003; https://doi.org/10.5065/ D61G0JGZ) and from Dai and Trenberth's Global River Flow and Continental Discharge data (Dai 2016; http://www.cgd.ucar.edu/cas/catalog/surface/dai-runoff/ index.html). Four stations met the uninterrupted monthly 
record criterion, three of which are in Thailand: Chiang Saen (ID 9342; $20.3^{\circ} \mathrm{N}, 100.1^{\circ} \mathrm{E} ; 1961-87$ ), Nakhon Phanom/Thakhek (ID 9343; $17.4^{\circ} \mathrm{N}, 104.8^{\circ} \mathrm{E} ; 1947-87$ ), and Mukdahan (ID 9340; $16.5^{\circ} \mathrm{N}, 104.73^{\circ} \mathrm{E} ; 1924-87$ ). The fourth, Pakse in Laos (ID 9903; $15.1^{\circ} \mathrm{N}, 105.8^{\circ} \mathrm{E}$; 1925-2005), has the longest record.

\section{e. Sea surface temperature}

SST on a $1^{\circ}$ global ocean grid from 1901 to 2015 is obtained from the HadISST dataset, version 1.1, (Rayner et al. 2003), produced by the UK Met Office (data are available from http://www.metoffice.gov.uk/hadobs/hadisst/ data/download.html).

The modes of recurrent SST variability, whose hydroclimate impact on the lower Mekong is assessed in this study, are extracted from an evolution-centric spatiotemporal analysis of the seasonal SST anomalies in the $20^{\circ} \mathrm{S}-70^{\circ} \mathrm{N}$ global domain in the twentieth century (1901-2015), following Guan and Nigam (2008). Two SST modes representing the growth and decay phases of canonical ENSO variability are assessed for hydroclimate impact. A common marker of ENSO variability-the Niño-3.4 SST index-was not used in the characterization of ENSO's impact on the Mekong basin as this index is keyed to ENSO's mature phase which occurs in boreal winter (the dry season in the lower Mekong). ENSO's impact on the Mekong basin precipitation is clearly of more interest in its rainy season (summer) and in the rainfall buildup (spring) and decay (fall) seasons, than in the dry season (winter).

\section{f. Analysis details}

The undertaken analysis is based on seasonal averages and anomalies, all following the boreal season definitions; for example, winter is the average of DecemberFebruary.

\section{Mekong basin water}

\section{a. In situ and satellite-based precipitation}

An assessment of the amount of water arriving as precipitation over the Mekong basin-a complex terrain basin-and the related amount that each country receives is a key goal of this study. The assessment is carried out using both in situ and satellite-derived precipitation data, in the interest of robustness. As noted earlier, in situ data are sparse and of uneven quality in complex terrains, while satellite-based records are limited in their duration. Prior to water budget assessments, the seasonal climatology from both precipitation datasets is compared in the overlapping data period (1998-2013) in Fig. 2. Immediately apparent, besides the close correspondence between the two climatologies, is that summer is the wet season and winter the dry one over the Mekong basin. The upper basin, at $1000-4000 \mathrm{~m}$ altitude in Tibet, has some frozen precipitation in winter that is not evident in Fig. 2 because a common contour interval was used in all seasons, and because the large winter-spring snowfall regions over the Tibetan Plateau are outside of the Mekong basin. Precipitation begins to increase in spring, especially over the lower basin. The precipitation increase at the end of spring is related to the buildup of the southwesterly monsoon, that is, to increased moisture transports from the Bay of Bengal, Andaman Sea, and the Gulf of Thailand.

The summer rainfall distribution, especially the large values along the west coast of SE Asia and in northeast India (Assam) and northern Myanmar (Kumon Range), reflect the important interception role of orography in draining moisture from the low-level southwesterly monsoon flow through forced ascent in the upstream regions (Xie et al. 2006); the large rainfall over these regions is a key water source for the Brahmaputra and Irrawaddy Rivers, respectively. Over the Mekong basin, summer rainfall is intense along the Thailand-Laos border in the midbasin, that is, in the region south of Vientiane and north of the Nakhon Phanom/Thakhek station; summer rainfall here is $12-14 \mathrm{~mm} \mathrm{day}^{-1}$; in comparison, summer rainfall over the Gangetic Plain is $\sim 9 \mathrm{~mm}^{\text {day }}{ }^{-1}$ (Ghosh et al. 2016). Precipitation decreases in fall with the region of maximum precipitation now located outside of the Mekong basin, along Vietnam's eastern coast. The monsoonal nature of rainfall, that is, one well-defined rainy season in the year, is challenging for the year-round management of water resources, especially in the densely populated lower Mekong.

Seasonal rainfall in any year typically differs from the long-term climatological value shown in Fig. 2. The strength of the interannual departures is often described by the standard deviation (SD) measure. Although not shown, the regions exhibiting large seasonal rainfall are also the regions of large SD; large positive departures here can generate devastating floods.

\section{b. Monthly precipitation volume}

The volume of water received as precipitation in the Mekong basin and in its subbasins is assessed using the recent 35-yr (1979-2013) climatology based on in situ data (GPCC). The assessment is important because, despite abundant summer rainfall, water remains a precious commodity in winter (the dry season) and even year-round during El Niño occurrence. Upbasin damming and climate change are additional hydroclimate stresses on the lower Mekong basin. 


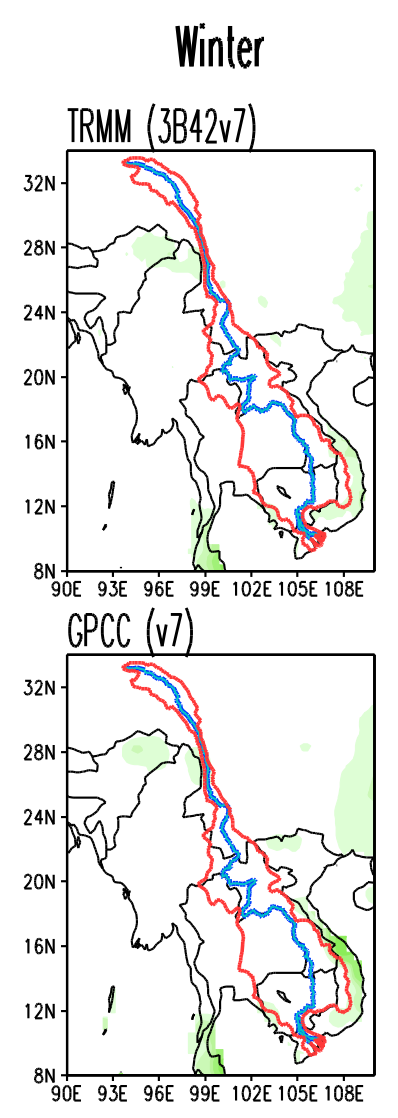

\section{Spring}
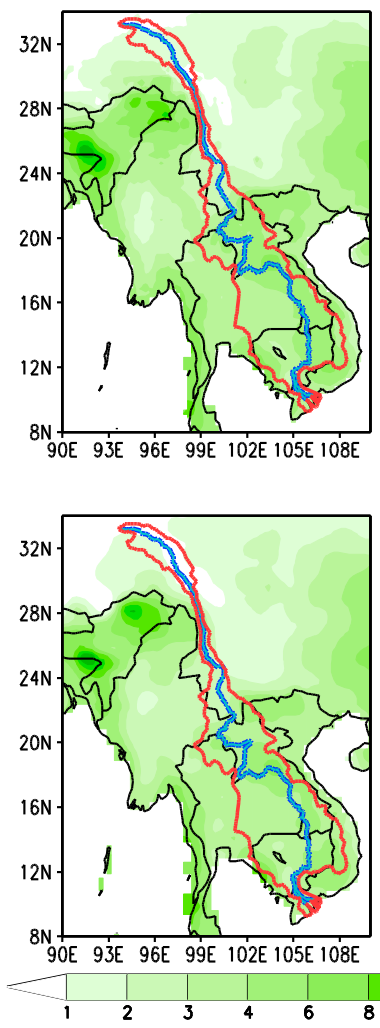

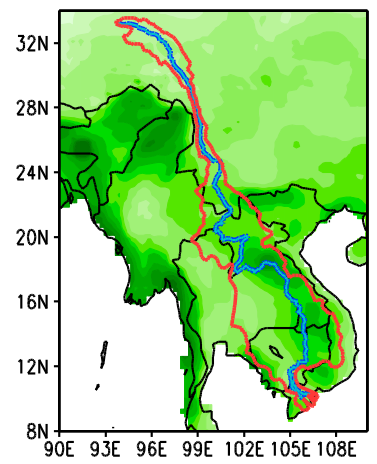

Summer

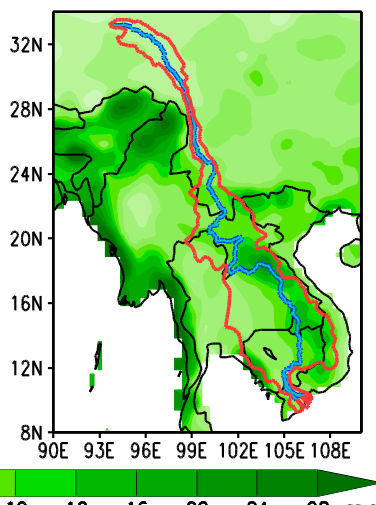

Foll
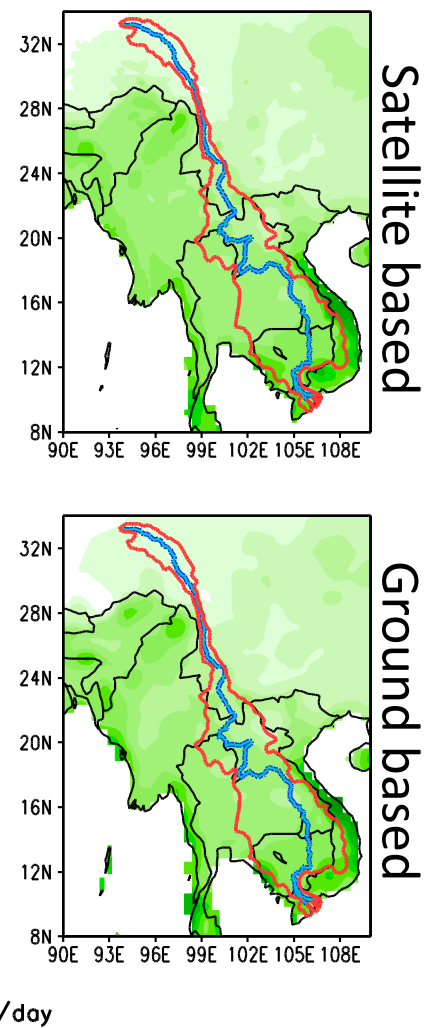

FIG. 2. Seasonal precipitation from the 1998-2013 period climatology: (top) space-based (TRMM $0.25^{\circ}$ latitude-longitude resolution daily data; Huffman et al. 2007) and (bottom) terrestrial station-based gauge data (GPCC, version $7 ; 0.5^{\circ}$ resolution monthly data; Schneider et al. 2017a,b). Green shading represents precipitation $\left(\mathrm{mm} \mathrm{day}^{-1}\right)$; the interval is $1 \mathrm{~mm} \mathrm{day}^{-1}$ initially, then $2 \mathrm{~mm}^{\text {day }}{ }^{-1}$ in the midrange (4-12 $\mathrm{mm} \mathrm{day}^{-1}$ ), and $4 \mathrm{~mm}$ day $^{-1}$ thereafter. The blue and red continuous lines denote the Mekong River and its basin boundaries, respectively.

The analysis of precipitation volume is preceded by graphical and tabular displays of area-averaged precipitation in the full basin and in each of its six subbasins. Monthly precipitation is plotted in Fig. 3 (top panel), and aspects of the distribution are noted in Table 1, the latter from both in situ (GPCC) and satellite-based (TRMM) precipitation. Winter is evidently the dry season $\left(<1 \mathrm{~mm} \mathrm{day}^{-1}\right)$ and summer the wet one $\left(>8 \mathrm{~mm} \mathrm{day}^{-1}\right.$, but for China) in the Mekong basin. Precipitation peaks in August except for Vietnam and Cambodia, where it is maximum in September, and in China where it peaks earlier in July. For the Mekong basin as a whole, January is the driest month and August the wettest (cf. Fig. 3). Annualmean precipitation averaged over the Mekong basin is $\sim 4.20 \mathrm{~mm} \mathrm{day}^{-1}$, with larger values $\left(>5 \mathrm{~mm} \mathrm{day}^{-1}\right)$ for Vietnam and Laos and the smallest ones $\left(\$ 2.5 \mathrm{~mm}^{-1 a y}{ }^{-1}\right)$ for China (cf. Table 1). Annual-mean precipitation is, however, not indicative of the relative contribution of these subbasins to Mekong basin water in view of the large variation in subbasin areas (Table 1, left column).
Multiplication of precipitation by basin area yields precipitation volume, whose monthly climatology is plotted in Fig. 3 (middle panel); the sum over all six subbasins is plotted using twice the scale (marked on the right edge). Area weighting leads to the emergence of Laos, Thailand, and Cambodia (in decreasing order) as the three leading contributors to Mekong basin water in summer (and spring and fall), with values in the $15-27 \times 10^{3} \mathrm{~m}^{3} \mathrm{~s}^{-1}$ range. Cambodia has higher summer rainfall but Thailand has a one-third larger subbasin, leading to the ranking switch. Interestingly, Vietnam with summer rainfall larger than Thailand, Cambodia, China, and Myanmar ranks fifth in contribution to precipitation volume, just above Myanmar's, because of the small area of the Mekong basin within its boundaries. The Chinese contribution to Mekong basin water ranks fourth in summer (and for much of the year). Similar rankings are obtained from the analysis of TRMM precipitation notwithstanding the data-sourcing and climatology- period differences (Table 1). For reference, the annual precipitation volume for the whole 

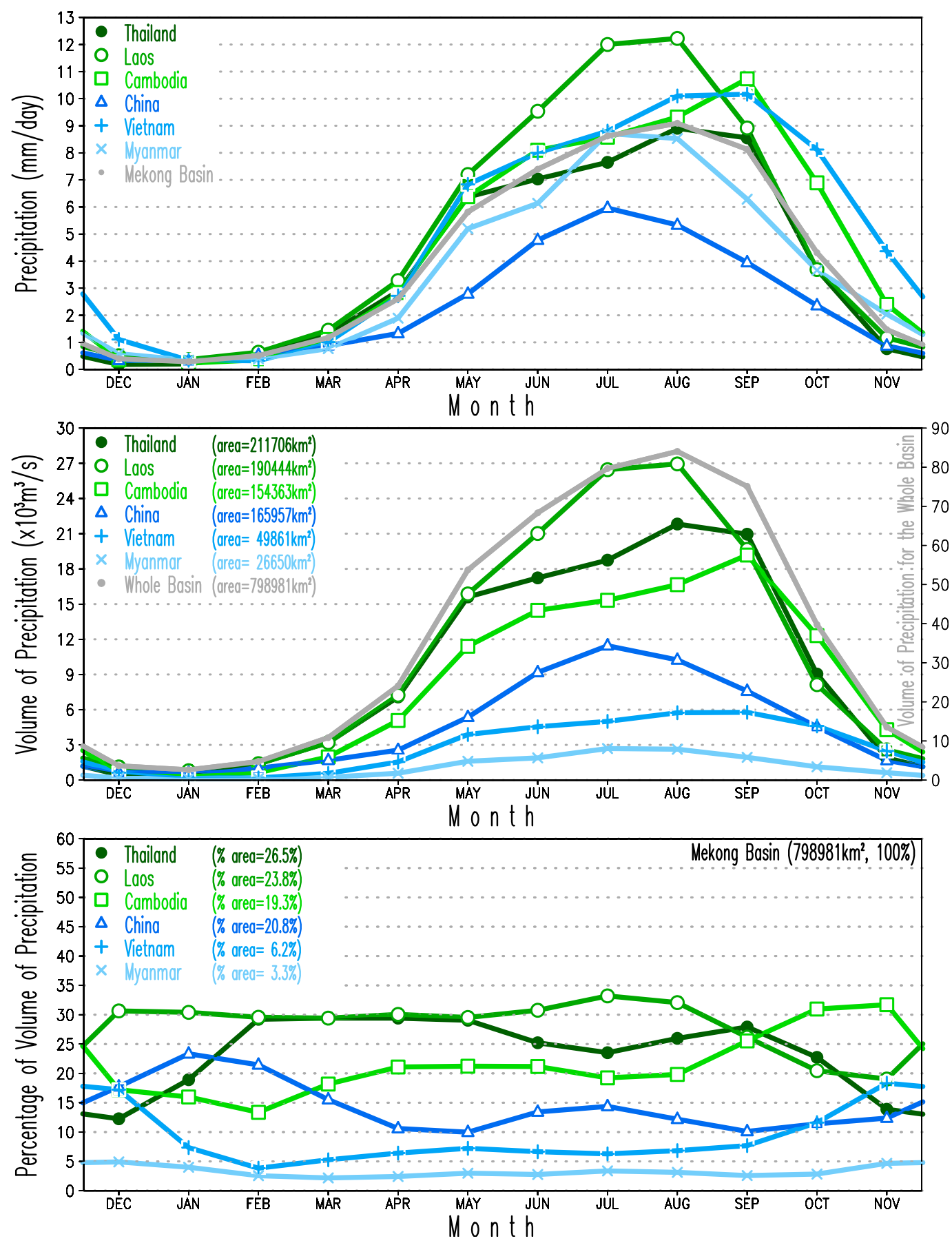

FIG. 3. (top) Average monthly precipitation over the Mekong basin lying within each country (mm day ${ }^{-1}$ ), (middle) basin area-weighted precipitation volume by country and for the whole basin $\left(\mathrm{m}^{3} \mathrm{~s}^{-1}\right.$; whole-basin values are plotted using the scale on the right), and (bottom) the country's percentage contribution to the total precipitation volume over the Mekong basin based on GPCC's $0.5^{\circ}$ precipitation climatology for the $1979-2013$ period, but with analysis on the $0.25^{\circ}$ grid. The Mekong basin area in each country is indicated in the legend and in Table 1 (left column), as is the total basin area.

basin is $482.84 \times 10^{3} \mathrm{~m}^{3} \mathrm{~s}^{-1}$ from TRMM and $460.09 \times$ $10^{3} \mathrm{~m}^{3} \mathrm{~s}^{-1}$ from GPCC data.

The relative contribution of the subbasins to Mekong basin water can be easily (even visually) assessed during spring-fall, but not in winter when all the subbasin contributions are small (Fig. 3, middle panel). A quantitative evaluation of the relative water input by each subbasin is provided in Fig. 3 (bottom panel), where this 
input is plotted as percent of Mekong basin water, at monthly resolution; Table 1 provides a similar assessment for the extended wet and dry periods and the annual average. The analysis shows the Laos contribution to be dominant ( $\sim 30 \%$ ) year-round, except during fall when Cambodia's contribution is higher. Thailand's contribution to Mekong basin water-the second largest overall (cf. Table 1) - is comparable to Laos in spring. Cambodia's water contribution ranks third for much of the year, except in fall when it leads all others. Vietnam and Myanmar's contribution are in the sub-10\% range across most months, except in fall when Vietnam's water contribution approaches the $20 \%$ mark. [Myanmar's small contribution to the Mekong basin water $(3 \%$ in terms of precipitation volume) does not reflect the overall precipitation distribution over the country. Precipitation is, in fact, abundant over western and northern Myanmar with two large rivers-Irrawaddy and Salween-sustained by this rainfall.]

Interestingly, China's contribution to Mekong basin water is between $10 \%$ and $15 \%$ in most months, except winter when it rises to $\sim 25 \%$ from its basin's exposure to midlatitude weather. Outside of winter, the contribution from the three lower Mekong countries (Laos, Thailand, and Cambodia) is $\sim 75 \%$ during MarchSeptember. Although Mekong basin water is not equivalent to Mekong streamflow despite the integration of precipitation in each case, the analysis reveals that the lower Mekong basin receives substantial water from precipitation, which, if stored and managed, can be a valuable asset during the dry winter season. The analysis moreover shows that even during winter, the Chinese contribution is surpassed by Laos' (30\%), and with Thailand's close behind, if not even, with the Chinese contribution.

\section{Mekong streamflow}

The Mekong basin water and Mekong streamflow are both integrated quantities: the former, computationally, while the latter, naturally, by the basin itself. A big difference though is that water losses have been factored into the latter: the precipitation reaching the basinMekong basin water-does not all end up as streamflow as some of the water evaporates, some is up taken by vegetation and transpired (evapotranspiration), some infiltrates the ground and recharges soil moisture (and aquifers), and some is stored in natural and man-made reservoirs, while the rest runs off and gravitationally channels into streamflow. The organization of streamflow thus takes time, leading to a delayed streamflow response to precipitation forcing. Measuring, monitoring, and modeling of water losses is challenging in view of the interaction among loss processes, let alone with the other regional climate elements. A hydrologic model representing key processes, for example, the Variable Infiltration Capacity model (VIC; Liang et al. 1994), can be deployed to estimate the water losses and model streamflow. The physiography of the Mekong basin, especially the steep southward sloping terrain of the upper and middle basins, however, prompted consideration of a simple conceptual model for relating the precipitation volume variations to those of streamflow.

\section{a. Climatological streamflow}

Modeling of streamflow was facilitated by the availability of monthly discharge records at four stations along the main stem of the Mekong River (cf. Fig. 1). The conceptual model, based on gravitational channeling, seeks to estimate the streamflow at any station by integrating the precipitation volume over the Mekong basin lying northward of that discharge station; the integration thus extends more southward for the downstream stations. Figure 4 shows the monthly climatology of integrated precipitation volume (green) and observed streamflow (black) at the four stations during the common period 1961-87; the upbasin precipitation volume is plotted using twice the scale (right axis) as for streamflow (left axis). Noteworthy features include the following:

- The amplitude of precipitation volume is twice that of streamflow, indicating that only about half of the upbasin precipitation makes it into the river; the other half is lost via processes noted earlier. The equipartition was, however, a surprise.

- Both precipitation volume and streamflow increase for the downstream stations, from the inclusion of more basin area in the integration and also larger rainfall values over the additional areas (cf. Fig. 2).

- Precipitation volume temporally leads streamflow; the lead is larger during the buildup to the wet season (summer) than after the wet season; at monthly resolution, the lead is $\sim 2$ months and $\sim 1$ month or less, respectively. As noted before, the processing of upbasin precipitation into streamflow is mediated by several processes, including soil moisture recharge, which leads to a delayed output. Why is the delay larger in the period before the wet season? It is because soil moisture is very depleted in late spring, following the dry season (winter) and just prior to the wet season (summer); with nearzero rainfall in winter, soil moisture stores are exhausted, awaiting recharge. ${ }^{1}$ Rainfall will thus not run off as

\footnotetext{
${ }^{1}$ Soil moisture is a minimum in the lower Mekong basin in April in the University of Delaware's terrestrial water-budget data archive (Willmott and Matsuura 2015).
} 

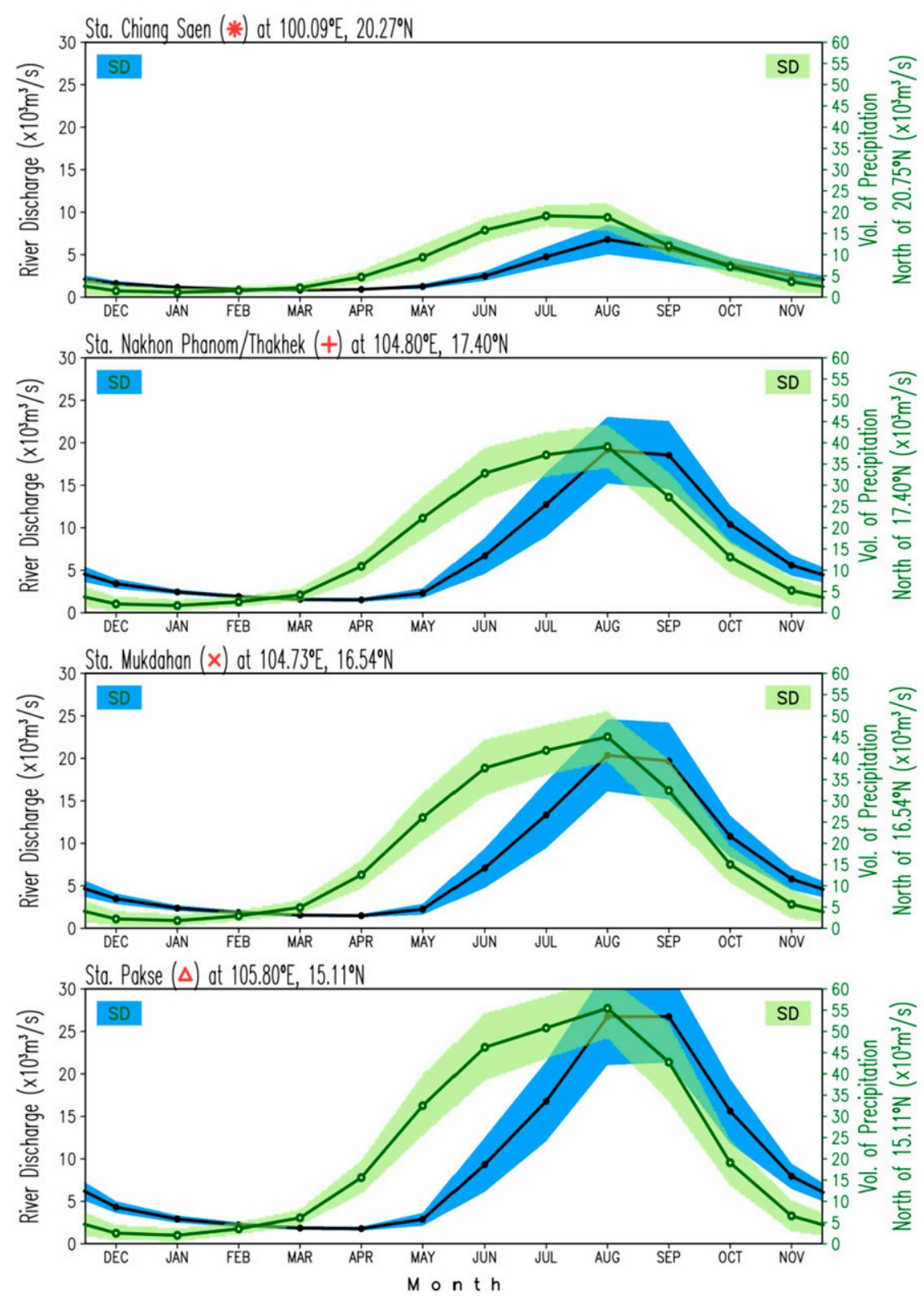

FIG. 4. Monthly climatology (line) and SD (shaded ribbon) of river discharge (i.e., streamflow) and upbasin precipitation volume (i.e., precipitation integrated over the Mekong basin lying northward of the discharge station) at four Mekong River gauge stations whose positions are marked in Fig. 1; the northernmost (southernmost) station is in the top (bottom) panel. Climatology and SD are based on the 1961-87 period, the common uninterrupted portion of the four records. The black line with a blue ribbon is for river discharge (left scale) and the dark green line with a green ribbon is for the upbasin precipitation volume (right scale, which is twice that on the left), both in units of $10^{3} \mathrm{~m}^{3} \mathrm{~s}^{-1}$. The ribbon denotes the $\pm 1 \mathrm{SD}$ range. Precipitation volume is computed from GPCC (version 7) data but on a $0.25^{\circ}$ grid.

quickly in late spring as it would with saturated soil in late summer. The post-wet-season delay ( $\$ 1$ month), in fact, provides a good estimate of the time taken by the upbasin precipitation to organize into runoff and gravitate toward the river bed; the basin physiography must be influential as the soil moisture capacitor is shorted at this time.

- The precipitation volume-streamflow delays in Fig. 4 are unlikely to have been influenced by dam operations, that is, their discharge and filling practices, because of 
the relatively small number of dams in the analysis period (13 dams in the 1960-89 period, as opposed to $81+$ now; cf. section 2) and that too of relatively modest capacity.

Although a quantitative model is still elusive, some strides were made in linking the upbasin precipitation volume with streamflow in the Mekong basin. Potential building blocks for the model are 1) the approximate equipartitioning of the upbasin precipitation volume into streamflow and water losses and 2) the empirical estimation of the pre- and post-wetseason delays between upbasin precipitation and streamflow.

\section{b. Summer streamflow anomalies}

The departures from climatology, or anomalies, are the focus here. Although a statistic of the anomaly amplitudes (standard deviation) was presented earlier (Fig. 4), the actual anomalies in upbasin precipitation volume (green) and streamflow (black) at the four river stations in summer are shown in Fig. 5a, this time using a common scale. Notable features include the following:

- The similar amplitude of the summer streamflow and precipitation volume anomalies: The factor of 2 amplitude difference manifest in climatological variations (Fig. 4) is not evident here. Note, this is not an artifact of seasonal (vs monthly) analysis, as the amplitude difference in summer would be expected to be, if anything, larger since the lower amplitude variable, streamflow, peaks in the postsummer months (Fig. 4).

- Consistent anomalies across stations: The positive 1970-71 anomalies, for example, are present in the streamflow and upbasin precipitation volume records of all four stations. Note that variations at the northernmost station (Chiang Saen) are plotted with half the scale used at other stations in order to resolve its low-volume flow variations.

- Consistent anomalies over time: The precipitation volume and streamflow anomalies are temporally well correlated during 1961-87, with a value of 0.8 at the three Thailand stations and 0.7 at the southernmost station (Pakse). Correlations decrease to 0.7 (except at Chiang Saen) when the period increases to 40 years (1948-87), to 0.5 at the two southernmost stations in the 63-yr period (1925-87), and to 0.45 at Pakse in the 81-yr period (1925-2005; see Fig. 5b).

- Streamflow anomalies no longer lag the precipitation volume ones: The two are, in fact, in sync, as noted above, quite unlike the climatological variations (Fig. 4). Why? Anomalies, riding on climatological variations, are less burdened by the loss processes, such as soil moisture recharge, especially in the wet season when the climatological precipitation is more than sufficient to fully quench seasonal deficits/recharge, leaving the anomaly component-the focus here-relatively unfettered.

- Declining precipitation volume and streamflow anomalies: Variations over the 27-yr period exhibit a decreasing linear trend as evident from the straight-line fits. The anomalies have comparable trends (magnitude and sign; Fig. 5a, legend) except at the southernmost station (Pakse), where the streamflow trend is almost half of the trend in precipitation volume, for reasons not understood.

- Note that declining precipitation trends over short periods, such as the 27-yr one analyzed in Fig. 5a, are not reflective of secular change. A significant trend over a much longer period, especially longer than the regional multidecadal variability time scales, is needed for such characterization. Figure $5 \mathrm{~b}$ plots the summer variability of the upbasin precipitation volume (and streamflow) at Pakse over an 81-yr period (1925-2005). The precipitation volume trend is much weaker now, and positive, while the streamflow trend remains negative, albeit much weaker than before. In short, the longer upbasin precipitation record at Pakse indicates that the upper and middle Mekong basin's hydroclimate has not been adversely impacted by secular warming. A long-term decline in streamflow despite an increasing upbasin precipitation volume, on the other hand, could reflect the increasing management of the Mekong River (see section 5).

\section{c. A simple hydrologic model for streamflow anomalies}

Analysis of the streamflow and upbasin precipitation volume anomalies at the four Mekong River gauge stations reveals the in-sync nature and similar amplitude of the interannual variations (Fig. 5), quite unlike the climatological ones (Fig. 4). From these two features, emerges a simple hydrologic model for the summer streamflow anomalies $S^{\prime}$, where

$$
S^{\prime}\left(\lambda_{S}, \theta_{S}, t\right)=\int_{\theta_{S}}^{\theta_{N}} d \theta \int_{\lambda_{W}(\theta)}^{\lambda_{E}(\theta)} P^{\prime}(\lambda, \theta, t) a^{2} \cos (\theta) d \lambda,
$$

where $a$ is the radius of Earth; $\theta_{N}$ the northernmost latitude of the Mekong basin; $\lambda_{S}$ and $\theta_{S}$ are the longitude and latitude, respectively, of the Mekong River station where streamflow anomaly $S^{\prime}$ is sought; $P^{\prime}(\lambda, \theta, t)$ are the precipitation anomalies; and $\lambda_{W}(\theta)$ and $\lambda_{E}(\theta)$ are the western and eastern longitudinal boundary, respectively, of the Mekong basin at any given latitude $\theta$. Note that the integral extends in latitude from the river station latitude $\theta_{S}$ until 
(a) River Discharge at Sta. Chiong Saen, Th (*⿻丷木 Up-basin Precipitation Volume
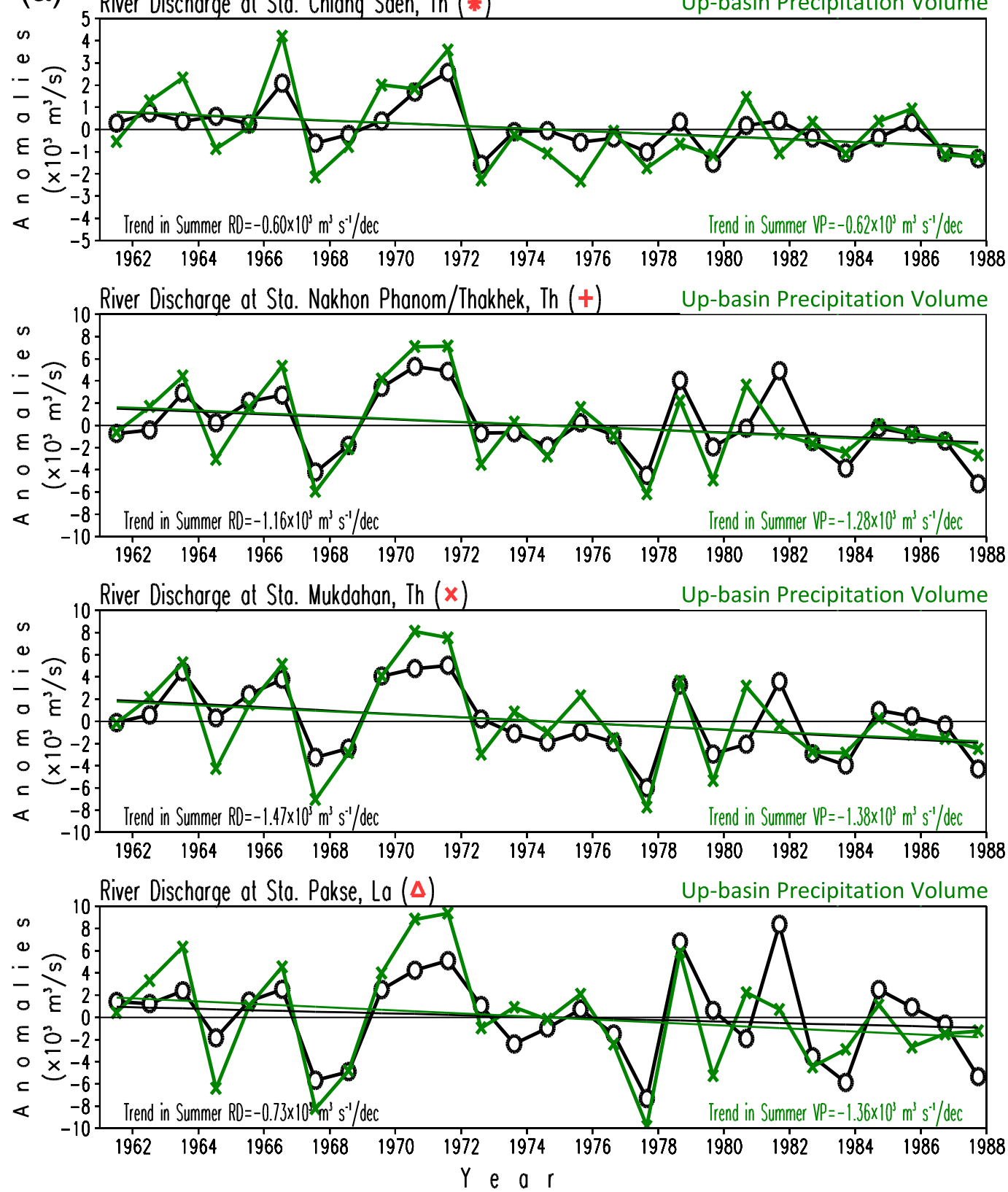

FIG. 5. (a) Summer departures from climatology, that is, the summer anomalies of river discharge and upbasin precipitation volume at four Mekong River gauge stations. Climatology and anomalies are based on the 1961-87 period. The black line is for river discharge and the dark green one for the upbasin precipitation volume; both shown, this time, with a common scale. The linear trend $\left(\mathrm{m}^{3} \mathrm{~s}^{-1}\right.$ decade $\left.^{-1}\right)$ in each variable is marked. The rest is as in Fig. 4.

the northern edge of the Mekong basin $\theta_{N}$, thus targeting the upbasin anomalies in precipitation volume.

\section{Influence of the upbasin dams on downstream flow?}

The detection of the influence of dams on the streamflow is challenging because the streamflow record contains superposed signals from regional hydroclimate variability and change as well as variable dam withholdings on account of both increasing dam numbers (cf. section $2 b$ ) and opaque dam-operation practices, especially the filling and discharge cycle timings. Despite these challenges, the dams' influence on the streamflow at Pakse (Laos) is investigated. Being the southernmost of the four analyzed river stations, streamflow at Pakse should 


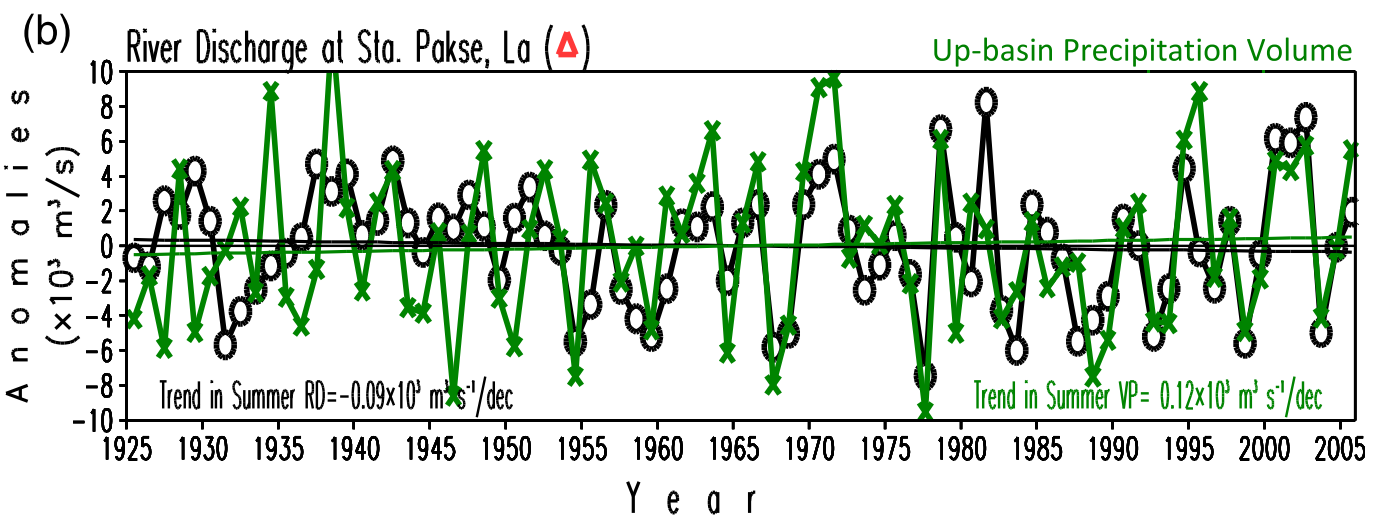

FIG. 5b. As in (a), but for summer anomalies of river discharge and upbasin precipitation volume at river station Pakse (Laos) during 1925-2005; the anomalies are with respect to the 1925-2005 climatology.

include an integrated signal of the upbasin dams. Its eightdecade-long record (1925-2005) moreover raises the prospects of signal detection. A hint that the dams' influence may be detectable is, perhaps, provided by the oppositely signed trends in Pakse streamflow (negative) and the upbasin precipitation volume (positive; Fig. 5b).

The deployed signal detection method is rudimentary. The 30-yr monthly climatology of streamflow is tracked over 10-yr-shifted periods, for example, 1936-65, 1946-75, ... 1976-2005; the choice of a 30-yr period for construction of climatology is consistent with the NOAA Climate Prediction Center's use of a 30-yr base period (1981-2010) for computing anomalies in the Climate Diagnostic Bulletin. The six climatologies are shown in Fig. 6, along with the number of dams in each 30 -yr period. Interesting variations seen in summer and fall must arise from multidecadal natural variability and the dams' influence. Lighter curves, which show the more recent climatologies, are generally on the inside of the darker ones, indicating declining streamflow in recent decades, especially in early fall (September-October), but the decline is not systematic as September's streamflow is smaller in the earliest climatology (1926-55; darkest blue) than it is in the following two, perhaps from the multidecadal natural variability of regional hydroclimate. The expression of this variability in more recent climatologies is likely overwhelmed by the increasing influence of dams in these climatology periods.

One consequence of the declining September streamflows is the eventual change in the month of peak streamflow at Pakse, from September until 1985 to August since. Can the dams be implicated? The increasing number of dams in the last two climatology periods (18 and 30) and the typical filling time of damsduring and just after peak rainfall—support the implication. The implication can be further strengthened if it can be shown that the early fall decline in Pakse streamflow occurs without any concurrent reductions in upbasin precipitation or increments in upbasin evapotranspiration. The six 30-yr upbasin precipitation (from GPCC) and evapotranspiration (from University of Delaware; Willmott and Matsuura 2015) volume climatologies are shown in the lower panel of Fig. 6. The upbasin precipitation volume peaks in August while the evapotranspiration losses peak earlier in June/July. Given the $\sim 1$-month delay in the organization of streamflow from upbasin precipitation in the post-wet season (cf. section 4a; Fig. 4, bottom panel), the focus should be on the change in the August volume, which, interestingly, exhibits a slight decrease in precipitation and a minimal increase in evapotranspiration from the early (1946-75) to the recent (1976-2005) period, but nowhere enough to account for the recent decrease in streamflow. The declining September streamflow at Pakse is thus not attributable to reduced upbasin precipitation, a finding that indirectly supports the implication of dams. ${ }^{2}$ The preliminary indications of the dams' influence on Pakse streamflow-declining flow in September without any upbasin precipitation reduction and evapotranspiration increase, and the related change in the peak-flow month from September to August-need

\footnotetext{
${ }^{2}$ A similar conclusion is reached from analysis of the University of Delaware terrestrial water-budget data archive (Willmott and Matsuura 2015), which, in addition to precipitation, provides monthly diagnosis of the soil moisture, evapotranspiration, and runoff fields. Precipitation here also peaks in August, much as in the GPCC-based precipitation analysis (Fig. 6). The upbasin precipitation minus evapotranspiration and runoff both peak in August but, more importantly, the decrease in water volume from the surface water variables in August is not enough to account for the reduced streamflow observed in September (Ruiz-Malca 2018). The effective removal of an important water loss term (evapotranspiration) from consideration in the attribution of decadal changes in Pakse streamflow supports the indirect implication of the upbasin dams for the recent change in Pakse peak-flow timing (from September to August).
} 
30-yr Climatologies within the Mekong River Basin
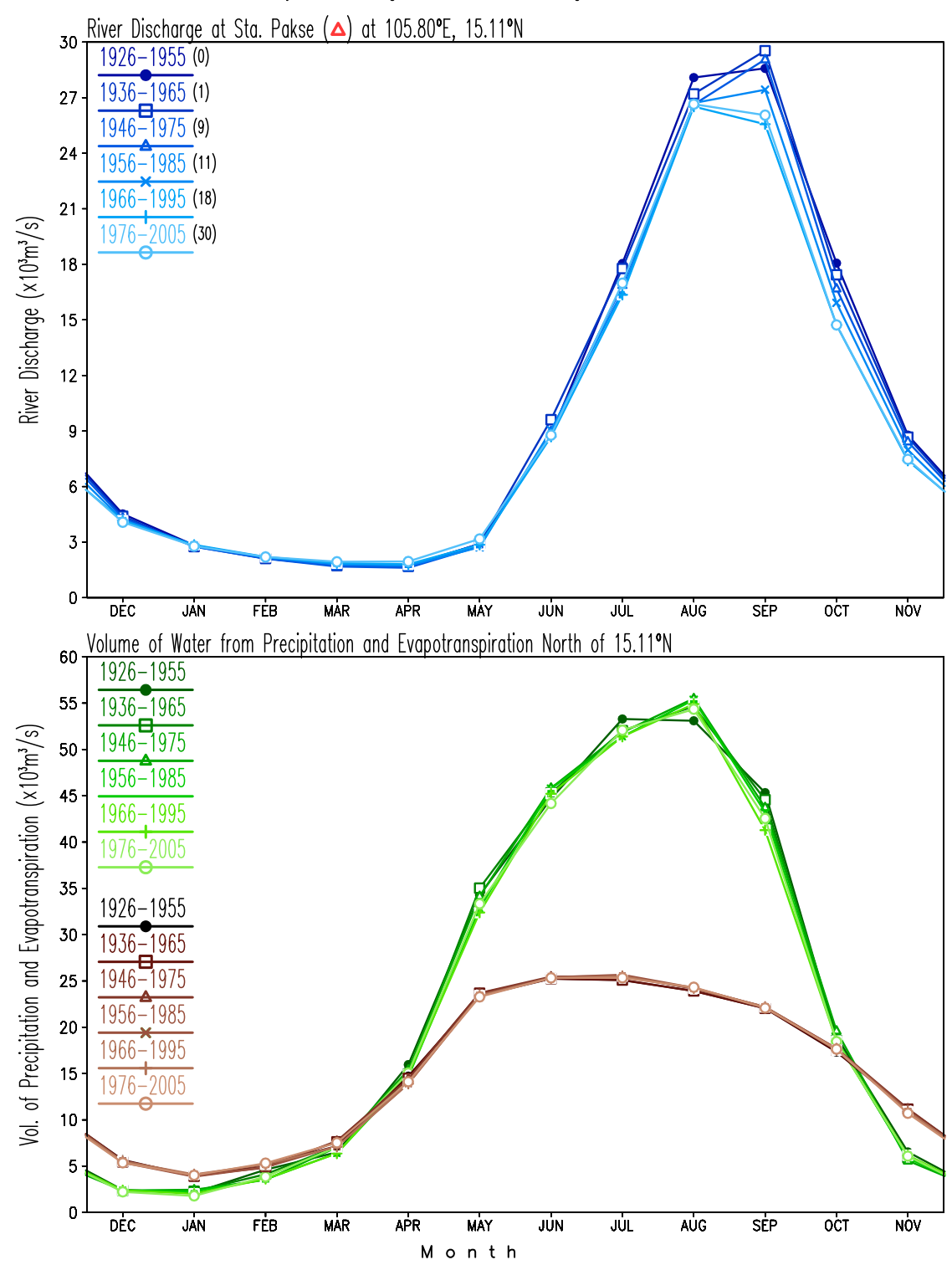

FIG. 6. Monthly climatology of river discharge (i.e., streamflow) at Pakse (Laos)-the southernmost of the four analyzed river stations, and marked with by a red triangle in Fig. 1and the upstream water volume gained from precipitation and lost through evapotranspiration. Changes in climatology are tracked over 10-yr-shifted 30-yr periods, for example, 1936-65, 1946-75, . . , 1976-2005. (top) The six climatologies along with the number of dams in each 30-yr period noted in the legend; lighter colors are used for the more recent periods. (bottom) The corresponding upbasin precipitation and evapotranspiration volume climatologies are shown in greens and browns, respectively, using twice the vertical scale of the upper panel. The precipitation volume is computed from GPCC (version 7) data, and the evapotranspiration volume is from the University of Delaware data but on a $0.25^{\circ}$ grid.

corroboration from in-depth analyses of the regional water cycle and dam operations.

The influence of upriver dams at proximal gauge stations (the signal) is relatively easier to detect, in view of the reduced exposure of streamflow to variations in the intervening basin precipitation and water loss processes (the noise), that is, from the higher signal-to-noise ratio. For example, the influence of Chinese dams on streamflow at Chiang Saen (Thailand) - the northernmost of the four stations marked in Fig. 1 (Pakse was the southernmost) -is well documented (Lu et al. 2014). 

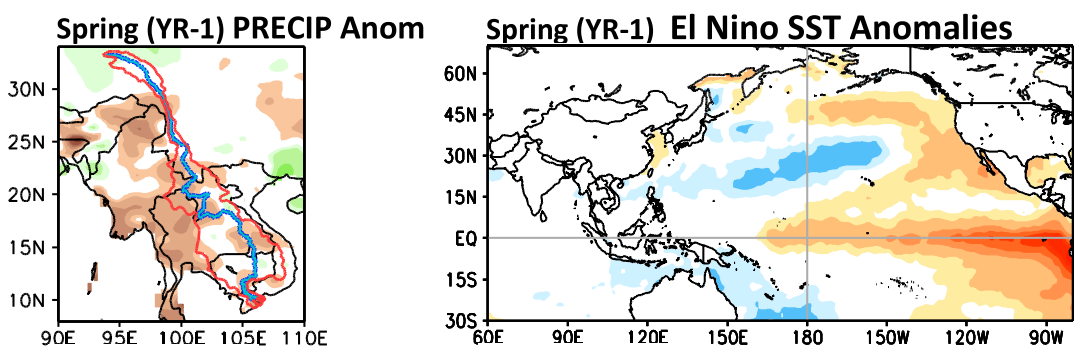

Summer (YR-1)

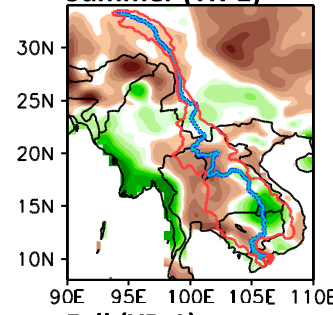

Summer (YR-1)

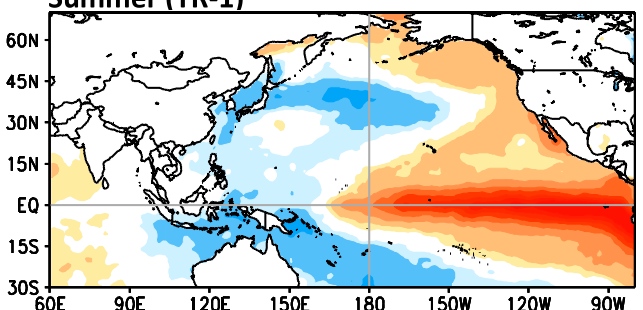

Fall (YR-1)

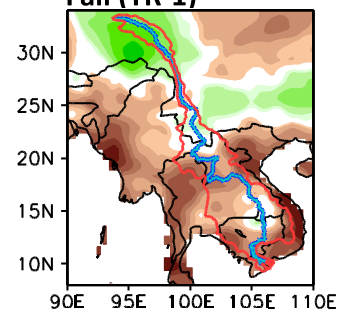

Fall (YR-1)
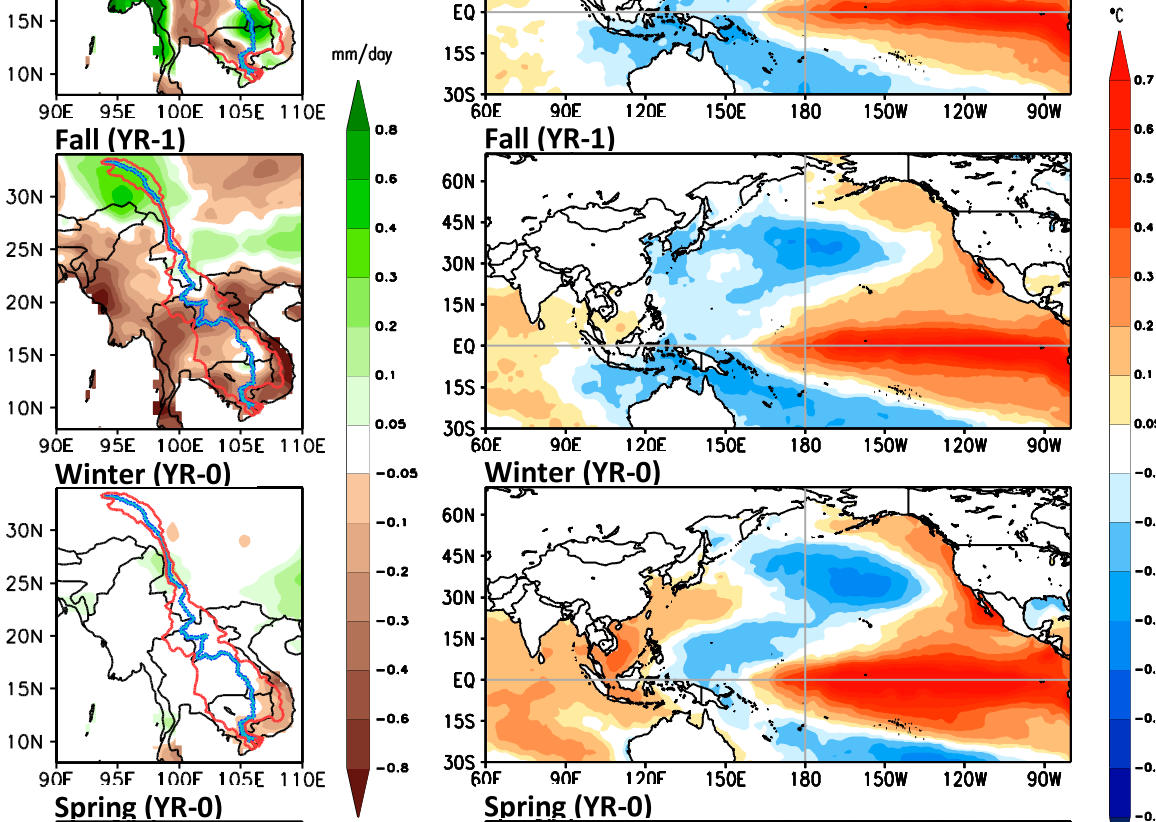

Spring (YR-0)

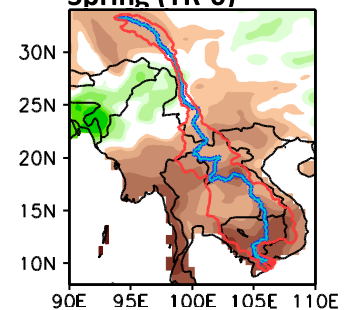

Spring (YR-0)

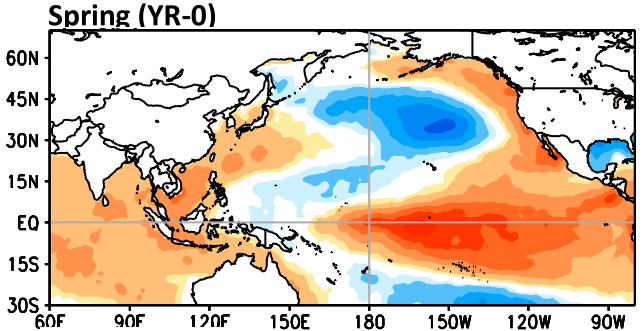

Summer (YR-0)
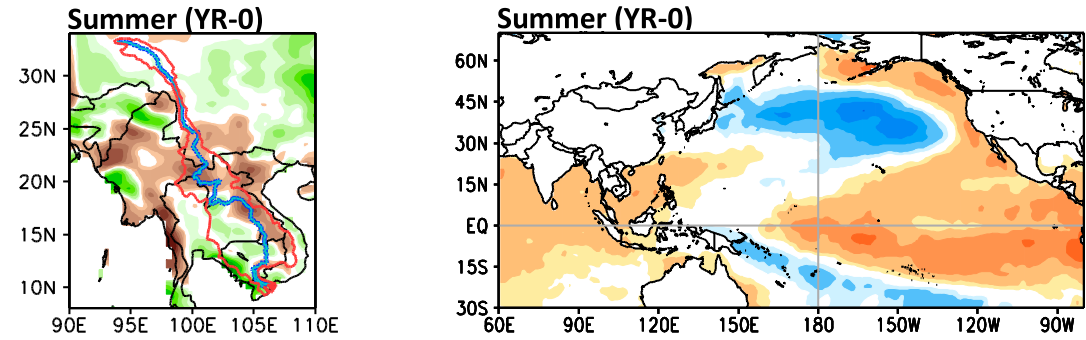

FIG. 7. (right) El Niño evolution and (left) its influence on Mekong basin precipitation. Canonical El Niño development begins in spring (YR-1), reaches its mature phase in winter (YR-0), and dissipates by summer (YR-0). The precipitation influence is obtained from regression analysis: seasonal precipitation ( $\mathrm{mm} \mathrm{day}^{-1}$ ) and SST $\left({ }^{\circ} \mathrm{C}\right)$ anomalies during 1901-2013 are regressed on the principal components representing canonical ENSO variability (see section 2c). Green (brown) shading represents precipitation above (below) the climatology; orange (blue) shading likewise represents SSTs warmer (cooler) than the climatology. 


\section{Impact of ENSO and climate change on the Mekong hydroclimate}

\section{a. El Niño-Southern Oscillation}

ENSO variability is rich, with individual ENSO episodes exhibiting interesting differences, or flavors (e.g., Capotondi et al. 2015). The rich spectrum of ENSO variability is a manifestation of the multiple recurrent spatiotemporal structures (or modes) of variability constituting ENSO and their varying lead lags. Guan and Nigam (2008) identified four underlying modesENSO growth and ENSO decay (representing canonical variability), ENSO noncanonical, and biennial-from an extended-EOF analysis of the seasonal SST anomalies. ENSO's complex spatiotemporal evolution was also noted by Compo and Sardeshmukh (2010), who caution against its filtering using just the Niño-3.4 SST index, a caution discussed in section 2e in the context of Mekong hydroclimate. Figure 7 shows the El Niño impact on Southeast Asian precipitation in all phases of canonical variability. It is assembled from the contemporaneous regressions of the 1901-2013 period precipitation anomalies on the principal component of the ENSOgrowth mode (yielding the top three panels, labeled YR-1) and the ENSO-decay mode (yielding the bottom three panels, labeled YR-0). Notable features include the following:

- The negligible precipitation impact in winter despite El Niño's peak amplitude at that time (as evident from the magnitude of the SST anomalies in Fig. 7); this is not surprising as winter is, climatologically, the dry season over the Mekong basin.

- The large precipitation impact in the fall preceding and the spring following El Niño's peak in winter, that is, in the seasons bookending the El Niño peak phase. Of the two, the spring following El Niño is more impactful, with large deficits over the entire Mekong basin, especially its sections in Laos and Cambodia. Deficits here are $\sim 0.4 \mathrm{~mm} \mathrm{day}^{-1}$ for an El Niño event whose peak-phase SST amplitude is $\sim 0.8^{\circ} \mathrm{C}$.

- The 2015/16 El Niño had peak SSTs of $\sim 3.0^{\circ} \mathrm{C}$, which should result in a precipitation deficit of $\sim 1.3 \mathrm{~mm}^{-1}{ }^{-1}$ over Laos and Cambodia in the spring of 2016. The deficit's significance is apparent from a comparison with the regional rainfall climatology $\left(6-7 \mathrm{~mm} \mathrm{day}^{-1}\right)$, which suggests that the 2015/16 El Niño episode resulted in a $\sim 20 \%$ reduction in spring rainfall. The dynamicalthermodynamical mechanisms generating El Niño's impressive impact on the Mekong hydroclimate, however, remain to be elucidated.

- El Niño's impact on the Mekong basin is larger than that indicated by the extent of its precipitation influence in the preceding fall and the following spring. El Niño's impact is amplified as the climatologically dry season (winter) is sandwiched between the two seasons exhibiting large precipitation deficits during El Niño. The amplification can be very challenging for the rain-fed, agriculture-dominated regional economies, as evident during the first half of 2016 - a period of record drought over the lower Mekong basin.

- El Niño SST anomalies in the seas surrounding the Malay Peninsula and lower Mekong are positive in the postpeak phase, consistent with the winter-spring warming of the Indian Ocean at that time (Nigam and Shen 1993, their Fig. 9). Can these warm SSTs weaken the land-ocean thermal contrast and thus the onset of the southwest monsoon over Indochina?

\section{b. Climate change}

The hydroclimate change over the Mekong basin (and SE Asia) is assessed from the century-long (1901-2013) linear trends in seasonal precipitation in Fig. 8. The upper Mekong is marked by year-round drying trends, which are especially strong in spring and summer. Over the lower Mekong, the drying trends are notable in summer and fall, especially over Cambodia, southeastern Thailand, southern Laos, and southern Vietnam; the drying trends in winter are not as consequential as winter is climatologically a dry season. The midbasin, comprising eastern Thailand and the southern half of Laos, on the other hand, exhibits positive precipitation trends in spring and summer, which should help offset some of the precipitation declines in the downstream region, at least in the context of the Mekong streamflow. The summer decline over northeastern Cambodia, for example, is more than $1 \mathrm{~mm}^{\text {day }}{ }^{-1}$ century $^{-1}$; that is, over a century-long period, the summer rainfall has declined by $\sim 1 \mathrm{~mm}$ day $^{-1}$. How significant is this? A comparison with climatological rainfall in the region (10-12 mm day $\left.{ }^{-1}\right)$ suggests that the centennial decline may be as large as $10 \%$.

\section{Principal findings and their policy implications}

The lower Mekong basin is approximately $\sim 10^{\circ}$ wide in longitude $\left(98^{\circ}-108^{\circ} \mathrm{E}\right)$ and latitude $\left(9^{\circ}-21^{\circ} \mathrm{N}\right)$ and lies within the northern tropics, surrounded by the Andaman Sea to the west, the Gulf of Thailand to the southwest, and the South China Sea to the east-southeast. Exposure to the southwest monsoon (with low-level, moistureladen onshore winds) brings copious rainfall in summer but, unlike the other monsoon regions of Asia (e.g., Indian subcontinent), the basin receives significant rainfall in other seasons as well, except winter. The Mekong basin 

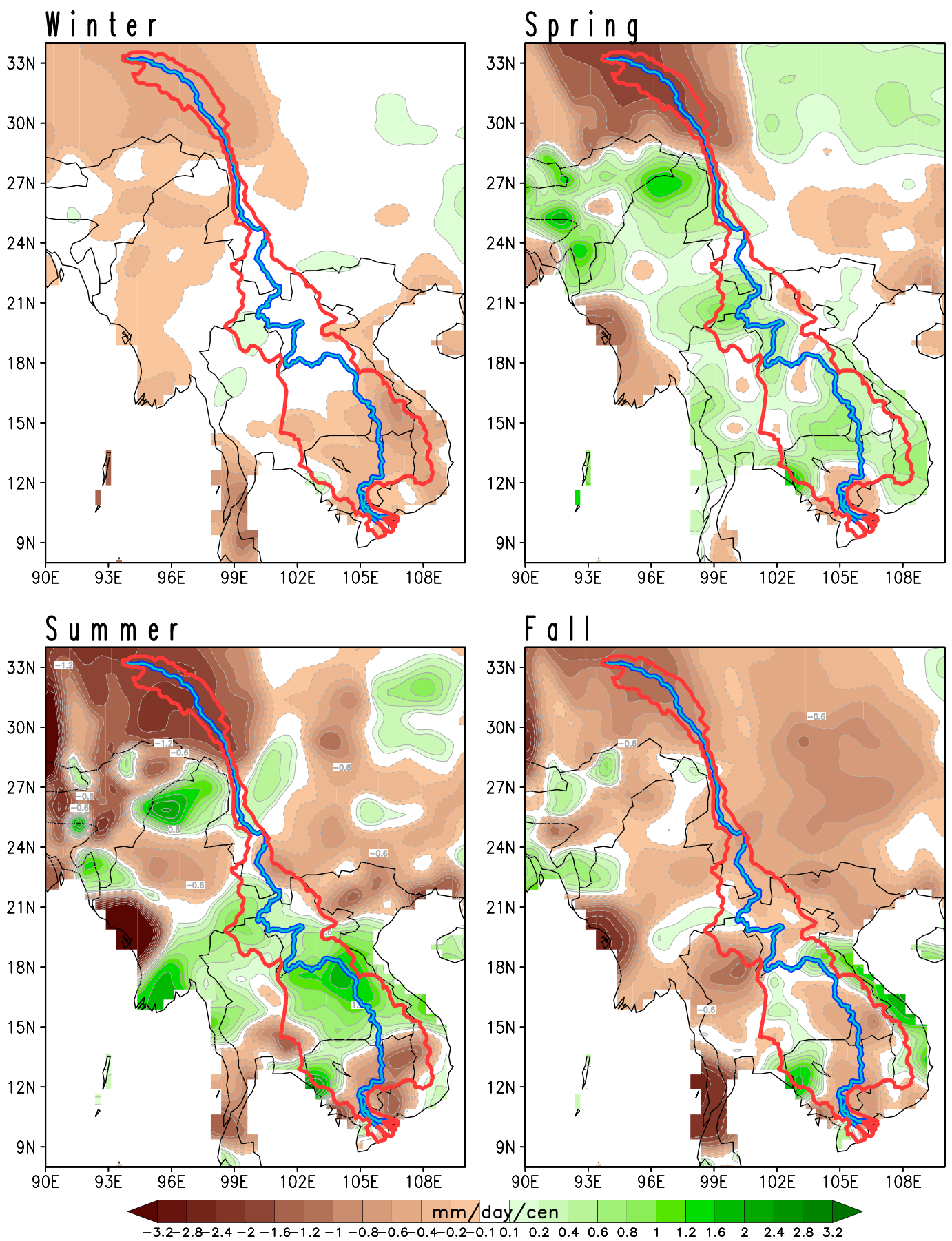

FIG. 8. Seasonal precipitation trends $\left(\mathrm{mm} \mathrm{day}^{-1}\right.$ century $^{-1}$ ) over SE Asia for the 1901-2013 period. Trends in the GPCC (version 7) data are plotted at $0.25^{\circ}$ resolution. Both the Mekong River and basin are marked (blue and red lines, respectively) for convenience. Green (brown) shading denotes regions of increasing (decreasing) precipitation.

is thus endowed with ample water on a per capita basis relative to other basins (FAO 2012). The river is the lifeblood of the agriculture-dominated economies of Thailand, Laos, Cambodia, and Vietnam. The riverine ecosystem with wetlands and mangrove forests further enhances the tropical fecundity.

Some management of the Mekong River is, perhaps, warranted to curb the annual flooding in late summer 
and early fall, notwithstanding the restorative fertility benefits to the floodplains. Such management can also help sequester water resources for the dry winter season and offset the saline water intrusions into the Mekong Delta during lean streamflow periods in winter and early spring. The southward sloping physiography of the Mekong basin has, however, elicited keen interest in the management of the river in view of its hydropower potential. The exploitation of this potential has led to the construction of several dams on the main stem of the river in China (and Laos), spawning transboundary tensions on water availability, fish migration, and sediment transport.

\section{a. Principal findings}

Analysis of the state-of-the-art in situ and satellitebased precipitation data on the high-resolution grid $\left(0.25^{\circ}\right.$ latitude-longitude) reveals that the Mekong subbasins of Laos, Thailand, and Cambodia (all lower Mekong) contribute $\sim 75 \%$ of the water received as precipitation in the full basin (the Mekong basin water) during March-September, while China's subbasin (upper Mekong) contributes $10 \%-15 \%$ in most months except winter when its contribution rises to $\sim 25 \%$.

Physiography of the Mekong basin, particularly its steep southward slope, instigated the development of a simple hydrologic model for relating streamflow at a river station with the amount of water received as precipitation in the entire Mekong basin lying northward of that station.

The simple model is based on the gravitational channeling of the upbasin precipitation. But such organization takes time (several weeks), leading to a temporal delay in the formation of streamflow. Intervening losses of water to evapotranspiration, soil moisture recharge, and infiltration additionally lead to an amplitude mismatch between the streamflow and the upbasin precipitation volume, as evident from the climatological analysis, where the amplitude mismatch is by a factor of $\sim 2$ and the streamflow development is delayed by $\sim 2$ months in the buildup to the wet season and by $\sim 1$ month or less in the post-wet season.

Interestingly, the amplitude mismatch and the delay in streamflow development disappear when the departures from climatology are modeled, leading to the emergence of a viable model for streamflow anomalies, one whose conceptual simplicity is appealing, especially in comparison with the commonly deployed hydrologic models (e.g., VIC).

Preliminary evidence for the impact of upbasin dams on downstream flow, especially on the timing of the peak summer flow, is presented; it needs corroboration from in-depth analyses of the regional water cycle and quantitative assessments of the dammed volume.
El Niño leads to significant rainfall reductions in the fall preceding and the spring following its peak phase; such reductions, at the bookends of the climatologically dry season in Southeast Asia (winter), generate drought conditions, as in 2015-16.

\section{b. Policy implications}

Tensions between upper and lower riparian regions are not uncommon, but they assume greater significance when these regions lie in different countries. Transboundary water issues in a region that lives off and by the river-the case in the Mekong basin - get cast as water security issues, and between unfriendly neighbors, escalate into national security concerns.

The Mekong basin is an interesting case study. The upper riparian country, China, an economic behemoth compared to any or even all of the lower riparian nations together, wields considerable sway over the basin, and not just because of its economic and industrial might. Aggressive posturing and assertion of sovereignty over internationally arbitrated common resources, such as the South China Sea, has rankled China's neighbors. Even more, it has instilled a sense of fear, cultivating resignation and acquiescence in the lower riparian countries, some of whom lack the technical expertise to take stock of their natural resources, even surface water.

The lower Mekong provides the perfect setting for the water security fears: China does control the headwaters of the Mekong and thus aspects of its downstream flow, which is the lifeblood of the lower riparian states. Inadvertent transference of China's economic and industrial might onto Mekong water issues, and yielding to instinctive ideas that the one who controls the headwaters also controls the river, have exaggerated China's influence on Mekong water.

Analysis of the highest spatial resolution ground and satellite-based precipitation data-the latter indispensable in the complex terrain of the upper basin (which lies in China)-suggests that the Mekong is largely a rainfed river, except in winter when it is also fed by Tibetan snowmelt. More importantly, the rain feeding the river falls largely over the lower basin (cf. Table 1, Fig. 3), giving the lower riparian nations significantly more control over water resources-more than they currently recognize. With prudent management, the surplus water of the rainy season (summer) can be sequestered for dry season (winter) use, fostering independence from the winter water releases from the upbasin Chinese/ Laos dams.

An awareness that China's influence on Mekong basin water may not be as significant as commonly perceived in the region, despite China's control of the 
Mekong headwaters, may lead to a more assertive lower Mekong region.

Technically, a quantitative characterization of ENSO's influence on the Mekong basin's hydroclimate-an impressive fall-to-spring drought (flooding) over the lower basin during El Niño (La Niña) occurrences-from objective analysis of the 113-yr long observational records (and not anecdotally) should spur the development of an operational regional drought (and flood) prediction system, leveraging off well-organized international efforts on ENSO prediction (e.g., International Research Institute for Climate and Society, Columbia University). This is one "low-hanging fruit" that is ripe for picking, that is, for rapid implementation, for example, at the Mekong River Commission.

Robust characterization of the hydroclimate change in the Mekong basin from an objective analysis of the century-long observational records indicates regional vulnerabilities that must be considered by regional governments and multinational institutions in the planning and design phase of the large infrastructure projects. Regional influence of multidecadal climate variability (not characterized in this study) should also be considered given that its time scale is comparable to the expected lifetimes of the large infrastructure projects.

Finally, the simple hydrologic model developed in this study needs to be refined in an experimental prediction mode targeting Mekong streamflow variations on dailyto-weekly time scales, leveraging off the high-resolution precipitation observations (satellite based, e.g., TRMM) and meteorological forecasts from cutting-edge weather prediction and data assimilation systems [e.g., the highresolution (HRES) forecast from ECMWF].

The present study is a prototype of the comprehensive space-based analyses of the regional atmospheric and terrestrial water cycles needed for assessment of the water stores in the solid, liquid, and vapor forms, and related fluxes. Such assessments can provide the objective technical underpinning of efforts targeting resolution of transboundary water issues, for example, in the context of the Indus Water Treaty (World Bank 1960).

Acknowledgments. The effort was motivated by the second author's affiliation with the U.S. State Department's Lower Mekong Initiative (LMI) through the Jefferson Science Fellowship from the National Academy of Sciences. The LMI program is managed by the State Department's Bureau of East Asian and Pacific Affairs, in particular, its Office of Multilateral Affairs (MLA). Sumant Nigam would like to thank Jacob Levin (LMI) for his encouragement to undertake this pilot-phase research in support of LMI's Forecast
Mekong initiative and Calvina Coleman (LMI) for sharing regional insights. This work would not have been possible without the indulgence of David Greene (MLA Director) and Jeffrey Graham (MLA Deputy Director), who gave Sumant Nigam the "space" to pursue this effort. MLA supported visits to the Mekong River Commission (MRC; Vientiane, Laos), Vietnam National Mekong Committee (VNMC; Hanoi), and NASA-USAID's SERVIRMekong Project (Bangkok), and regional consultations with Dr. Pham Tuan Phan (CEO, MRC), Dr. Le Duc Trung (Director General, VNMC), and Dr. Peter Cutter (SERVIR-Mekong) were helpful. Sumant Nigam would like to thank Jenny Frankel Reed (USAID) and Dr. John Bolten (NASA) for the regional introductions that led to productive visits. Sumant Nigam thanks the University of Maryland for granting him a 1-yr leave of absence in support of the Jefferson Fellowship, and the National Academy of Sciences for providing a serene work environment. Both authors gratefully acknowledge the support of the National Science Foundation through NSF Grant AGS1439940 to the University of Maryland. All of the analyzed datasets are publicly available and their sources are clearly stated. We thank editor Ruby Leung and the two reviewers, including Vasu Misra, for their careful reading and helpful advice in improving the manuscript. The views expressed are the authors' alone and not reflective of the U.S. National Academies or the U.S. State Department.

\section{REFERENCES}

Adamson, P. T., I. D. Rutherfurd, M. C. Peel, and I. A. Conlan, 2009: The hydrology of the Mekong River. The Mekong: Biophysical Environment of an International River Basin, I. C. Campbell, Ed., Elsevier, 53-76, https://doi.org/10.1016/ B978-0-12-374026-7.00004-8.

Amante, C., and B. W. Eakins, 2009: ETOPO1 1 arc-minute global relief model: Procedures, data sources, and analysis. NOAA Tech. Memo. NESDIS NGDC-24, 25 pp., https://www.ngdc. noaa.gov/mgg/global/relief/ETOPO1/docs/ETOPO1.pdf.

Bertiz, J., 2017: Identifying climate change and variability in the Philippines and Indochina Peninsula: The Maritime Continent. Research Practicum Paper, Eleanor Roosevelt High School, $58 \mathrm{pp}$.

Buckley, B. M., and Coauthors, 2010: Climate as a contributing factor in the demise of Angkor, Cambodia. Proc. Natl. Acad. Sci. USA, 107, 6748-6752, https://doi.org/10.1073/pnas.0910827107.

Capotondi, A., and Coauthors, 2015: Understanding ENSO diversity. Bull. Amer. Meteor. Soc., 96, 921-938, https://doi.org/ 10.1175/BAMS-D-13-00117.1.

CGIAR, 2017: Water, land and ecosystems dataset on dams of the Irrawaddy, Mekong, Red and Salween River basins. CGIAR Research Program on Water, Land, and Ecosystems, accessed 27 April 2018, https://wle-mekong.cgiar.org/maps/.

Church, J. A., N. J. White, R. Coleman, K. Lambeck, and J. X. Mitrovica, 2004: Estimates of the regional distribution of 
sea level rise over the 1950-2000 period. J. Climate, 17, 2609-2625, https://doi.org/10.1175/1520-0442(2004)017<2609: EOTRDO $>2.0 . \mathrm{CO} ; 2$.

Compo, G. P., and P. D. Sardeshmukh, 2010: Removing ENSOrelated variations from the climate record. J. Climate, 23, 1957-1978, https://doi.org/10.1175/2009JCLI2735.1.

Dai, A., 2016: Historical and future changes in streamflow and continental runoff: A review. Terrestrial Water Cycle and Climate Change: Natural and Human-Induced Impacts, Geophys. Monogr., Vol. 221, Amer. Geophys. Union, 17-37, https://doi.org/10.1002/9781118971772.ch2.

_- , and K. E. Trenberth, 2003: New estimates of continental discharge and oceanic freshwater transport. 17th Conf. on Hydrology, Long Beach, CA, Amer. Meteor. Soc., JP1.11, https://ams.confex.com/ams/annual2003/techprogram/ paper_55037.htm.

Daiss, T., 2016: Why Vietnam is running dry, worst drought in nearly 100 years. Forbes, 25 May, https://www.forbes.com/ sites/timdaiss/2016/05/25/why-vietnam-is-running-dry-worstdrought-in-nearly-100-yrs/\#7f27e01274b3.

Delgado, J. K., B. Merz, and H. Apel, 2012: A climate-flood link for the lower Mekong River. Hydrol. Earth Syst. Sci., 16, 1533 1541, https://doi.org/10.5194/hess-16-1533-2012.

FAO, 2012: Irrigation in southern and eastern Asia in figures: AQUASTAT Survey-2011. FAO Water Rep. 37, 512 pp., http://www.fao.org/docrep/016/i2809e/i2809e.pdf.

Ghosh, S., H. Vittal, T. Sharma, S. Karmakar, K. S. Kasiviswanathan, Y. Dhanesh, K. P. Sudheer, and S. S. Gunthe, 2016: Indian summer monsoon rainfall: Implications of contrasting trends in the spatial variability of means and extremes. PLOS ONE, 11, e0158670, https://doi.org/10.1371/journal. pone. 0158670 .

Guan, B., and S. Nigam, 2008: Pacific sea surface temperatures in the twentieth century: An evolution-centric analysis of variability and trend. J. Climate, 21, 2790-2809, https://doi.org/ 10.1175/2007JCLI2076.1.

Guha-Sapir, D., R. Below, and Ph. Hoyois, 2017: EM-DAT: The CRED/OFDA International Disaster Database. Université Catholique de Louvain, www.emdat.be.

Hijioka, Y., and Coauthors, 2014: Asia. Climate Change 2014: Impacts, Adaptation, and Vulnerability. Part B: Regional Aspects, Cambridge University Press, 1327-1370.

Hoque, M. A., P. F. D. Scheelbeek, P. Vineis, A. E. Khan, K. M. Ahmed, and A. P. Butler, 2016: Drinking water vulnerability to climate change and alternatives for adaptation in coastal South and South East Asia. Climatic Change, 136, 247-263, https://doi.org/10.1007/s10584-016-1617-1.

Huffman, G. J., and Coauthors, 2007: The TRMM Multisatellite Precipitation Analysis: Quasi-global, multi-yr, combinedsensor precipitation estimates at fine scales. J. Hydrometeor., 8, 38-55, https://doi.org/10.1175/JHM560.1.

Jenness, J., J. Dooley, J. Aguilar-Manjarrez, and C. Riva, 2007a: African Water Resource Database: GIS-based tools for inland aquatic resource management-1. Concepts and application case studies. CIFA Tech. Paper 33/1, FAO, 167 pp., http:// www.fao.org/docrep/010/a1170e/a1170e00.htm.

$\ldots, \ldots$, and $-2007 \mathrm{~b}$ : African Water Resource Database: GIS-based tools for inland aquatic resource management-2. Technical manual and workbook. CIFA Tech. Paper No. 33/2, FAO, 308 pp., http://www.fao.org/docrep/010/ a0907e/a0907e00.htm.

Larson, C., 2016: Mekong megadrought erodes food security. Science, 6 April, https://doi.org/10.1126/science.aaf9880.
Liang, X., D. P. Lettenmaier, E. F. Wood, and S. J. Burges, 1994: A simple hydrologically based model of land surface water and energy fluxes for general circulation models. J. Geophys. Res., 99, 14 415-14 428, https://doi.org/10.1029/94JD00483.

Lu, X. X., L. Siyue, M. Kummu, R. Padawangu, and J. J. Wang, 2014: Observed changes in water flow at Chiang Saen in the lower Mekong: Impacts of Chinese dams? Quat. Int., 336, 145-157, https://doi.org/10.1016/j.quaint.2014.02.006.

Misra, V., and S. DiNapoli, 2014: The variability of the Southeast Asian summer monsoon. Int. J. Climatol., 34, 893-901, https:// doi.org/10.1002/joc.3735.

MRC, 2005: Mekong River Commission: Overview of the hydrology of the Mekong basin. Mekong River Commission, 73 pp., http://www.mekonginfo.org/assets/midocs/0001968-inland-watersoverview-of-the-hydrology-of-the-mekong-basin.pdf.

Nigam, S., and H.-S. Shen, 1993: Structure of oceanic and atmospheric low-frequency variability over the tropical Pacific and Indian oceans. Part-I: COADS Observations. J. Climate, 6, 657-676, https://doi.org/10.1175/1520-0442(1993)006<0657: SOOAAL $>2.0 . \mathrm{CO} ; 2$.

Office of the Resident Coordinator Viet Nam, 2016: Viet Nam: Drought and saltwater intrusion. UN Viet Nam Situation Rep. 7, 5 pp., http://www.un.org.vn/en/publications/doc_details/ 526-viet-nam-drought-and-saltwater-intrusion-situation-reportno-7-as-of-25-october-2016.html.

Räsänen, T. A., and M. Kummu, 2013: Spatiotemporal influences of ENSO on precipitation and flood pulse in the Mekong River basin. J. Hydrol., 476, 154-168, https://doi.org/10.1016/ j.jhydrol.2012.10.028.

_ , V. Lindgren, J. H. A. Guillaume, B. M. Buckley, and M. Kummu, 2016: On the spatial and temporal variability of ENSO precipitation and drought teleconnection in mainland Southeast Asia. Climate Past, 12, 1889-1905, https://doi.org/ 10.5194/cp-12-1889-2016.

Rayner, N. A., D. E. Parker, E. B. Horton, C. K. Folland, L. V. Alexander, D. P. Rowell, E. C. Kent, and A. Kaplan, 2003: Global analyses of sea surface temperature, sea ice, and night marine air temperature since the late nineteenth century. J. Geophys. Res., 108, 4407, https://doi.org/10.1029/ 2002JD002670.

Ruiz-Malca, A., 2018: Impact of climate variability, change and damming in streamflow of the Mekong River. Research Practicum Paper, Eleanor Roosevelt High School, $54 \mathrm{pp}$.

Schneider, U., P. Finger, A. Meyer-Christoffer, E. Rustemeier, M. Ziese, and A. Becker, 2017a: Evaluating the hydrological cycle over land using the newly-corrected precipitation climatology from the Global Precipitation Climatology Centre (GPCC). Atmosphere, 8, 52, https://doi.org/10.3390/ atmos 8030052 .

— M. Ziese, A. Meyer-Christoffer, P. Finger, E. Rustemeier, and A. Becker, 2017b: The new portfolio of global precipitation data products of the Global Precipitation Climatology Centre suitable to assess and quantify the global water cycle and resources. Proc. Int. Assoc. Hydrol. Sci., 374, 29-34, https:// doi.org/10.5194/piahs-374-29-2016.

Son, D. M., and P. Thuoc, 2003: Management of coastal fisheries in Vietnam. Assessment, management and future directions for coastal fisheries in Asian countries, G. T. Silvestre et al., Eds., WorldFish Center Conf. Proc. 67, 957-986, http://pubs.iclarm. net/resource_centre/proceedings.pdf.

Wang, W., H. Lu, D. Yang, K. Sothea, Y. Jiao, B. Gao, X. Peng, and Z. Pang, 2016: Modelling hydrologic processes in the 
Mekong River basin using a distributed model driven by satellite precipitation and rain gauge observations. PLOS ONE, 11, e0152229, https://doi.org/10.1371/journal.pone.0152229.

Wang, Y. Q., 2014: MeteoInfo: GIS software for meteorological data visualization and analysis. Meteor. Appl., 21, 360-368, https://doi.org/10.1002/met.1345.

Willmott, C. J., and K. Matsuura, 2015: Terrestrial water budget data archive: Monthly time series (1900-2014) (V. 3.01). Accessed 20 October 2015, http://climate.geog.udel.edu/ climate/ html_pages/Global2014/GlobalWbTs2014.html.

World Bank, 1960: Indus Water Treaty 1960. World Bank, 24 pp., http:/siteresources.worldbank.org/INTSOUTHASIA/Resources/ 223497-1105737253588/IndusWatersTreaty1960.pdf.

WWF, 2017: Greater Mekong. World Wildlife Fund, accessed 23 February 2017, https://www.worldwildlife.org/places/greatermekong.
Xie, S.-P., H. Xu, N. H. Saji, Y. Wang, and W. T. Liu, 2006: Role of narrow mountains in large-scale organization of Asian monsoon convection. J. Climate, 19, 3420-3429, https://doi.org/ 10.1175/JCLI3777.1.

Xue, Z., J. P. Liu, and Q. Ge, 2011: Changes in hydrology and sediment delivery of the Mekong River in the last 50 years: Connection to damming, monsoon and ENSO. Earth Surf. Processes Landforms, 36, 296-308, https://doi.org/10.1002/esp.2036.

Yokoi, S., T. Satomura, and J. Matsumoto, 2007: Climatological characteristics of the intraseasonal variation of precipitation over the Indochina Peninsula. J. Climate, 20, 5301-5315, https://doi.org/10.1175/2007JCLI1357.1.

Zhang, Y., T. Li, B. Wang, and G. Wu, 2002: Onset of the summer monsoon over the Indochina Peninsula: Climatology and interannual variations. J. Climate, 15, 3206-3221, https://doi.org/ 10.1175/1520-0442(2002)015<3206:OOTSMO>2.0.CO;2. 